\title{
A Primary Diagnosis of the Limiting Factors of Doing Micro, Small and Medium Scale Businesses in Two Municipal Local Government Areas of Cross River State, Nigeria
}

\author{
Ndem Ayara, Joe Eba and Uwem Essia \\ Department of Economics, University of Calabar, Calabar Cross River State - Nigeria
}

\begin{abstract}
This study sought to examine growth requirements of MSMEs based on primary data gathered from two local government areas in Cross River State - Calabar South and Calabar Municipality. The method of random sampling was used to select 3,660 respondents for the administration of structured questionnaire instrument for data collection. Data collected and analysed covered employment behavior, enterprise owners' demographics, enterprise type and sector, bankability, and accessibility to Business Development Support (BDS) services. Other information elicited was on business formalization, growth prospects of enterprises, and taxation. Information collected was analyzed and summarized using simple percentages. Findings show that in both LGAs, enterprises required capacity building in specialized technical, managerial and marketing fields for business startups. Interest charges by banks, ignorance, and poor access to loans were leading limiting factors confronting MSMEs in both LGAs. It was also revealed that low purchasing power, inadequate knowledge, large number of dependants, unfair tax system and insecurity were the leading de-enablers of enterprise growth. The study recommended the provision of Business Development Support (BDS) services targeted at budding microenterprise owners and aspiring entrepreneurs, especially women, the physically challenged and other vulnerable groups, and people living in communities with limited banking services.
\end{abstract}

Key Words: MSMEs, BDS, MEDA and Growth

\section{Background}

Cross River State economy is dominated by primary economic activities with few secondary and tertiary services mostly in the tourism and hospitality sub-sector. Government remains the major employer of labour in the formal sector and source of funding for the economy. Private sector productivity has remained low, and most successful businesses are linked directly or indirectly to government. The low private sector contribution to the economy expectedly affects Government's capacity to generate revenue internally, and like many other sub-national governments in Nigeria, over 80 percent of state government's revenue is received from the Federation Account. Redressing this trend, calls for strong commitments to private participation, promotion and support.

Sectoral growth indicators of the state indicate that agriculture contributed 48.05 percent of the State Gross Domestic Product (GDP), services contributed 51.93 percent. Manufacturing contributed a paltry 0.003 percent, while solid minerals contributed 0.02 percent between 2007 and 2012. The service sector covers construction, tourism and hospitality, "other services", government services, electricity \& water, and oil \& gas. "Other services" covers trade, transportation, storage and communication, real estate \& business services, social \& personal services, financial services, and domestic services. Overall average annual growth rates declined significantly from 10.34 percent in 2007 to 2.95 percent in 2008 . It rose mildly to 3.05 percent in 2009 and reached 3.29 percent in 2012. The high growth rate of 10.34 percent in 2007 was accounted for by huge spending of the state government, which surged expenditures for construction, government services, and water and electricity. It is noteworthy, however, that in addition to huge receipts from the Federation Account, which accounted for over 90 percent of total financial resource inflow, the Donald Duke led administration (19992007) borrowed to finance many of the monumental developments in infrastructure and tourism development. Efforts by the succeeding Senator Liyel Imoke led administration (2007-2015) to meet repayment terms, was shocked witha sharp decline in federal allocation to the State due to oil well value transfer to the neighboring Akwa Ibom state resulted in significant decline in Federation Account receipts since after 2009. Overall six-year average (2007-2012) economic growth rate of the Cross River State economy was below the national average for most of the period. 
Table 1: Selected Sectoral Growth Indicators in Cross River State (2007-2012)*

\begin{tabular}{|c|c|c|c|c|c|c|c|c|}
\hline \multirow[t]{2}{*}{ Indicator } & \multirow{2}{*}{$\begin{array}{l}\text { Share in GSP } \\
(2007-2012)\end{array}$} & \multicolumn{6}{|c|}{ Growth Rate (Percent) } & \multirow{2}{*}{$\begin{array}{lr}\text { Average } \\
\text { Growth } \\
\text { percent } \\
\text { 2012) }\end{array}$} \\
\hline & & 2007 & 2008 & 2009 & 2010 & 2011 & 2012 & \\
\hline Agriculture & 48.05 & 5.71 & 6.90 & 6.10 & 6.23 & 6.25 & 6.28 & 6.26 \\
\hline Services & 51.93 & 18.96 & 4.89 & 4.09 & 4.31 & 4.39 & 4.40 & 6.84 \\
\hline Construction & 5.61 & 6.32 & 4.12 & 4.05 & 4.23 & 4.26 & 4.30 & 4.55 \\
\hline $\begin{array}{ll}\begin{array}{l}\text { Tourism } \\
\text { hospitality }\end{array} & \& \\
\end{array}$ & 3.50 & 3.21 & 3.02 & 3.10 & 3.12 & 3.19 & 3.21 & 3.14 \\
\hline Other Services & 4.90 & 6.96 & 10.96 & 11.96 & 11.72 & 11.88 & 11.83 & 10.89 \\
\hline $\begin{array}{l}\text { Government } \\
\text { Services }\end{array}$ & 2.00 & 49.41 & 8.43 & 3.11 & 4.23 & 4.31 & 4.29 & 12.30 \\
\hline Electricity \& Water & 0.02 & 40.00 & 1.67 & 1.21 & 1.33 & 1.43 & 1.42 & 7.84 \\
\hline Oil \& Gas & 34.90 & 7.83 & 1.13 & 1.12 & 1.25 & 1.28 & 1.35 & 2.33 \\
\hline Manufacturing & 0.003 & 0.001 & 0.001 & 0.001 & 0.002 & 0.003 & 0.005 & 0.002 \\
\hline Quarry \& Mining & 0.02 & 16.67 & 0.01 & 2.00 & 2.25 & 2.28 & 2.43 & 4.27 \\
\hline \multicolumn{2}{|c|}{ Annual growth rates (Percent) } & 10.34 & 2.95 & 3.05 & 3.20 & 3.23 & 3.29 & 4.34 \\
\hline
\end{tabular}

* Provisional

Source: State Planning Commission (2013)

From Table 1 it is clear that the real sector of the State is dominated by activities in agriculture, solid minerals, and tourism and hospitality. Major agricultural produce of the state includes rice, oil palm, cassava, rubber, Banana, Plantain, vegetables, fruits, and raffia palm. Common livestock activities are piggery and poultry. Fishing is the traditional occupation of people in riverside communities, but fish ponds of different sizes were common. The forest communities of the statemainly in Akamkpa, Akpabuyo, and Biase local government areas harvest timber, herbal roots, leaves, and barks, edible vegetables (like afang, editan, and utasi) from the forest. Other benefits of the forests include hunting of "bush animals", felling trees for fuelwood, and collection of fodder for domestic animals. In the solid mineral sector, LGAs within the zone have limestone, granite, sand (of different variety and mineral content), and clay. Limestone is a major ingredient used for the manufacture of cement, and a cement manufacturer, UNICEM Ltd., is located within the zone. Another cement manufacturer Dangote Cement is hoping to start business. Dangote is already a global player, and it is hoped that its products will target both local and export markets.

The Growths and Employment in States (GEMS 3) studies (2012) re-echoed concerns raised by the World Bank Doing Business in Nigeria Sub-national Report (2010), and other globally accepted business environment benchmarking authorities, on the need to render business environment in the State more competitive and hospitable. Specifically the World Bank studies noted that Cross River State ranked $33^{\text {rd }}$, Kano $8^{\text {th }}$, and Jigawa $1^{\text {st }}$ out of the 36 States and Abuja, the Federal Capital Territory in Nigeria. Decomposing the composite indicators further, Cross River State was ranked $35^{\text {th }}$ for starting business, $17^{\text {th }}$ for dealing with construction permits, $20^{\text {th }}$ for registering property, and $37^{\text {th }}$ for enforcing contracts. Notably, Cross River State was considered the most costly place to start a business in Nigeria. It cost more than 100 percent of per capita income to start business in Calabar, while for other States and Nigeria it cost on average between 70 and 80 per cent. Legal processing and obtaining approvals contributed to the high cost of starting business in Cross River State. With regards to enforcing contracts, again it was found that Cross River provided the lengthiest legal process of 835 days, followed by Kano with 720 days, while Kaduna and Lagos had between 400 and 500 days.

Other challenges for doing business in the State noted by the GEMS 3 report were low traffic of Calabar seaport. The port could not handle modern large vessels and the Manufacturers Association of Nigeria (MAN) estimates that extra transportation costs due the incapacity was between $\mathrm{N} 200,000$ and $\mathrm{N} 300,000$ per consignment.Despite being illegal, roadblocks and various forms of illegal rent seeking added extra cost to trucks plying federal highways. There was no cargo airport in the State, and Calabar airport could not handle large international aircrafts due to short runway.Multiple taxation and nuisance levies added significantly to cost of doing business. 43 percent of firms (compared to 21 percent national average) indicated that excessive taxation raised the cost of doing.

This study is aimed at diagnosing the basicrequirements for optimal growth and sustainability of Micro, Small and Medium scale Enterprises (MSMEs) in Calabar South and Calabar Municipality, which are the two Local Government Areas (LGAs) that make up the State Capital of Cross River State, using primary data collected through a web-based survey. The study will assist the design of appropriate business development services (BDS) and other interventions for microenterprises and potential entrepreneurs. Information obtained from the study can be used by other State and Federal MDAs as baselines for future sustainability checks. The research output will equally assist development partners such as donors, Non-Governmental Organisations (NGOs), and other private sector groups in their empowerment and promotional activities. 
The paper is sub-divided into five parts. Following the background is the conceptual underpinnings in Part 2. Area of study and research methodology occupies Part 3, while Part 4 dwells on discussion of the findings. Finally, the paper ends with recommendations and conclusion in Part 5.

\section{Conceptual Underpinnings}

Microenterprise Development Strategy (MDS) is championed, globally, on the premise that skills development and micro-financing can unleash the entrepreneurial capacities of those who have lacked access to mainstream business capital and services. MDS should promote business startups and growth of enterprises, increase personal income for enterprise owners, and support job creation. The target market for MDS is often defined broadly as budding microenterprise owners and aspiring entrepreneurs; especially women, the physically challenged and other vulnerable groups, and people living in communities with limited banking services (Edgcomb and Thetford, 2013).

Basically, MDS provides technical and financial assistantships. Such services are intended to reduce the learning curve, and increase longevity, growth, and structural transformation of microenterprises. MDS are commonly provided by community-based nonprofit groups, government agencies, Foundations, Industry Membership Organizations (IMOs), and philanthropists. At the microeconomic level, successful adoption of Microenterprise Development Strategy (MDS) should lead to reduction in cost of doing business, increase in revenue, assets and personal profits, improvement in economic self-sufficiency for poor families, increase in business skills and self-esteem, and improved access to community resources and credit opportunities. At the macroeconomic level, more investors will be attracted; inflation rates become responsive to growing productivity, and economic growth more inclusive (Edgcomb and Thetford, 2013).

Gulani and Usman (2013) in a study of Gombe State, identified poor financing as a major factor inhibiting development of MSMEs in Nigeria. The study noted that personal savings and support from family members were the most convenient sources of venture capital to many people, and majority of poor people are bypassed by both the banking system and BDS services of government. Seibel (2007) opines also that government-induced capital transfers and concessionary lending generally favour large firms and the rich class, while micro-entrepreneurs, women, and other poorer segments of the population are excluded. Accordingly, BDS should necessarily include substantial microfinance composites to, among other things, effectively mobilize the poor's own resources, through savings and equity, and augment them with other forms of domestic savings to achieve financial inclusion. Additionally therefore, MDS should support business startups and expansion of microenterprises, with accessible and affordable loans; encourage microenterprises to formalize and submit to appropriate regulation and supervision; promote enterprise clustering, and development of networks of product and value chains; and, ensure that more enterprises are linked to stable local and export markets.

Seibel (2007) advises however that in striving to promote financial inclusion, BDS should be prioritized accordingly to the following sub-segments of the economy:Firstly, the rural poor, particularly residents of disadvantaged or marginal areas;Secondly, all segments of the rural population, particularly nonagricultural entrepreneurs; And thirdly, commodity producers, processors and traders. The third sub-segment is critical for the value chains and linkages it is capable of generating. The challenge however is to turn creditworthy demand for financial services into sustainable supply of financial services. Accordingly, the BDS matrix of the commodity sector should therefore focus on demand and supply stimuli as follows:

a) Demand side stimuli - promotion of value creation through processing and marketing goods in line with market needs.

b) Supply side stimuli - a shift away from charity and interest rate subsidies towards dynamically growing sustainable financial services on reasonably commercial terms.

In line with Seibel (2007), Kanayo et al. (2013) note that microenterprise owners in Nigeria generally have access to limited formal banking services, and traditional moneylenders charge exorbitant interest rates, which significantly limits borrowing to finance businesses. Oteh (2009) proposes that firms owned by the poor can be encouraged to form clusters that seek business financing together, provide collective guarantees, and in the long term establish their own financial institutions. Experiences from SMEs' development in Asia have shown that the relationships formed by such networked firms often make it easier to obtain concessionary loans and other BDS services. Working together also eases access to credit supply of raw materials and other inputs, and other traded goods and services. Olu (2009) rightly notes that a key response to challenges of industrial transformation in developing countries is encouraging enterprise clustering and reducing biases against informal activities and small enterprises.

Review of selected literature identified value chain creation through processing and marketing of the desired goods, on the demand side, and a shift away from charity and subsidies towards sustainable financial services on reasonably commercial terms, on the supply side, as the winning Microenterprise Development 
Strategy (MDS) adopted in a number of best practice countries. How the strategy can work in practice was illustrated with the Growth-Oriented Microenterprise Development (GMED) programme, spearheaded by a government agency, to foster growth of MSMEs in India. More specifically, India's GMED indicates that Microfinance and Enterprise Development Agency (MEDA) can promote enterprise development by promotion of enterprise clustering and value chains development, distinguishing between rural and urban-based interventions with customized implementation strategies, developing market making strategies to stimulate mass production, creating collaborative platforms that link human empowerment to entrepreneurship culturing, linking entrepreneurship with crosscutting issues of gender, environment, and HIV/AIDS, and promoting research and development (R\&D) collaborations of enterprises, innovators and research institutions.

\subsection{Cross River State Microfinance and Enterprise Development Agency (MEDA)}

In Cross River State, Microfinance and Enterprise Development Agency(MEDA) was established in 2011 to offer Business Development Services (BDS). Its core goals include; promotion of mindset change, facilitation of funding for microenterprises, coordination of entrepreneurship development and other skills' acquisition programmes, and support for business formalization and co-operativisation. The overall goal is to help enterprises and potential entrepreneurs surmount teething challenges and grow sustainably. Some recent BDS services of the MEDA of Cross River State, Nigeria, on Micro, Small, and Medium Enterprises (MSMEs) in the State include:

i. Training of 15 trainers in each of the 18 LGAs. The key training areas were rural telephony (with support from Airtel), ICT, preparation of enterprise plans, and marketing.

ii. Collaborating with the Ministry of Agriculture, CRS Agriculture Development Agency (ADP), and First Bank Plc on the Yam Business Development Programme.

iii. Initiating Project Awake, where 20 women per Ward were supported (there were 196 Wards). Programmes for training of 'techno-preneurs' with marketable ICT skills were equally developed.

iv. Initiating discussions on creating a "Basket Fund" and "Credit Bureau" for microenterprises by combining finance levered from banks (at lower interest rates) with State funds. This is instructive as the Cross River State of Nigeria Small Scale Industries (Credit Scheme) Law. CAP.S7 (1973) empowers the State to create a basket fund for micro-enterprises.

v. Working with Small and Medium Enterprises Development Agency of Nigeria(SMEDAN), Ministry of Science \& Technology, and National Board for Technology Incubation on establishing an enterprise incubation centre in the State.

The above achievements notwithstanding, recent studies on Investment Climate, and the other on Tax Harmonization in the State by GEMS 3, a DFID funded project, conducted in 2012 and 2013 respectively, noted that for MEDA to be more result oriented in the delivery of BDS services, it should develop updatable databases on enterprises showing characteristics of entrepreneurs, enablers/de-enablers of enterprise growth and performance. Other recommendations were programmes for promoting business formalization, cooperativisation, and industry-public dialogues (IPDs), a sustainable human capacity building strategy, a workable mechanism for linking enterprises and budding entrepreneurs to innovators, research organizations, and tertiary education faculties, a robust M\&E framework for tracking the performance of beneficiaries of its BDS services, and sourcing of affordable loans for enterprises and potential entrepreneurs.

\subsection{India's Experience with Microenterprise Development}

A review of Growth-Oriented Microenterprise Development (GMED) programme by Olu (2009) and USAID (2008) illustrate how BDS spearheaded by a government agency successfully fostered growth of MSMEs in India. GMED was an innovative programme under India's Accelerated Microenterprise Advancement Project (AMAP). GMED's end objectives were for scaling up widespread industry adoption of innovations and new knowledge; increased incomes earned by MSEs; and improved socio-economic well-being of MSMEs owners/operators and employees of key value chain participants.

GMED initially commenced work in three agribusiness subsectors, namely; integrated broiler industry, organically-certified food products, and fresh fruits (mangos) and vegetables in the agribusiness subsector, and one urban services subsector, namely; municipal solid waste management. The three agribusiness subsectors were chosen because they appeared to offer the best opportunities for smallholder farmers' income growth.GMED started producing organically-certified food products including maize through widespread deployment of financial assistance, extension services support, and market facilitation. Thereafter progress was made on the integrated broilers industry, which was linked to the maize value chain by ensuring the use of locally harvested maize to produce poultry feed. GMED later progressed to taking advantage of emerging opportunities in the organized retail sector and the rapidly growing demand for fresh fruits and vegetables. The municipal solid waste management focused on ensuring environmental sanitation and adding value through 
recycling. GMED was solely a technical service program and had no grant or subsidy component, making it unique for donor support.More specifically, GMED's agribusiness and urban services components has the were the Agribusiness component - focusing on fruits and vegetables, organically certified food products, maize value chain improvement, and integration of HIV/AIDS-affected communities into commercial supply chains; and the Urban services component - working to improve municipal solid waste management and recycling through outsourcing to MSMEs.

\section{GMED adopted the following strategies:}

(i) Strengthening the value chains through partnerships: GMED operated more as a service facilitator, rather than a service provider, coordinating and synchronizing the support services provided by a wide ranch of public and private entrepreneurship development stakeholders and partners.

(ii) Developing maize-processing technology: GMED worked with the major feed mills to strengthen ties between farmers and maize users and to introduce technology for improving farmer productivity and product quality. GMED's industry partner, the largest Indian feed milling firm, set up village collection centers in maize-producing regions to facilitate market making.

(iii) Producing organically certified food: GMED helped two large NGOs establish commercial marketing subsidiaries; improve their management and processing procedures, and linkages with more profitable markets. The NGOs effectively organized and obtained organic certification for several thousand small, marginal, mostly women farmers. GMED guided development of the NGOs' skills to effectively market the certified products.

(iv) Solving waste management problems and benefiting the informal sector: through its solid waste management subcomponent, GMED provided training and guidance to municipal governments in three states for the outsourcing of solid waste management activities to MSMEs. GMED's outsourcing tool kit has been introduced to at least 40 municipal governments and was chosen as an implementing instrument by other donors, including the World Bank.

(v) Linking smallholder fruit and vegetable farmers to retail food sector markets: GMED helped several major Indian corporations and larger NGOs integrate smallholder farmers into commercial supply chains by increasing their capacity to meet market demand. Although starting from a very small base, the organized retail food sector in India experienced rapid growth. The project improved farmers' productivity and product quality and addressed other value chain gaps in the post-harvest and marketing sectors.

(vi) Integration of HIV/AIDS persons into productive activities: GMED organized several smallholder farmer clusters in HIV/AIDS-affected areas to join commercial vegetable supply chains, based on an assured market for their products.

\subsection{Lessons from India's GMED}

Key lessons from India's Growth-Oriented Microenterprise Development (GMED) programme for microenterprise development in Cross River State are summarized in Table 2 below:

Table 2: Lessons from India's GMED for Microenterprise Development in CRS

\begin{tabular}{|c|c|c|}
\hline Lessons from GMED & Any related MEDA's Activity & $\begin{array}{l}\text { Imperatives for microenterprise } \\
\text { development in CRS }\end{array}$ \\
\hline $\begin{array}{l}\text { Selected strategically, for active } \\
\text { suppor, sub-sectoral activities with } \\
\text { potentials for growing value chains } \\
\text { and linking other sectors. }\end{array}$ & $\begin{array}{l}\text { MEDA has ongoing support initiatives for } \\
\text { cassava and yam farmers, and other } \\
\text { entrepreneurs that are not linked } \\
\text { particularly to growing value chains. }\end{array}$ & $\begin{array}{l}\text { MEDA needs to develop and manage } \\
\text { programmes for enterprise clustering } \\
\text { and development of value chains. }\end{array}$ \\
\hline $\begin{array}{l}\text { GMED distinguished between rural- } \\
\text { and urban-based interventions. This } \\
\text { allowed it to creatively serve needs } \\
\text { of the different groups of support } \\
\text { seekers without neglecting any } \\
\text { group. }\end{array}$ & $\begin{array}{l}\text { The targeted beneficiaries of MEDA's } \\
\text { support programmes are the rural poor, } \\
\text { but MEDA is essentially based in } \\
\text { Calabar, the State capital. There were few } \\
\text { clearly delineated rural and urban based } \\
\text { interventions. }\end{array}$ & $\begin{array}{l}\text { MEDA should clearly distinguish its } \\
\text { rural and urban based programmes, and } \\
\text { identify the most appropriate strategy } \\
\text { for implementing each set of } \\
\text { interventions. }\end{array}$ \\
\hline $\begin{array}{l}\text { GMED focused on products and } \\
\text { activities with strong market } \\
\text { prospects. Sound market making } \\
\text { rendered growth of the supported } \\
\text { enterprises self sustaining. }\end{array}$ & $\begin{array}{l}\text { MEDA focuses principally on training } \\
\text { and financing facilitation. There were few } \\
\text { initiatives for supported enterprises to } \\
\text { secure local or export markets. }\end{array}$ & $\begin{array}{l}\text { MEDA needs to develop clear market } \\
\text { making strategies for its beneficiary } \\
\text { enterprises, products and activities. }\end{array}$ \\
\hline $\begin{array}{l}\text { GMED operated as a facilitator, not a } \\
\text { service provider; coordinating the } \\
\text { empowerment projects of other } \\
\text { government agencies, NGOs, and } \\
\text { donors. }\end{array}$ & $\begin{array}{l}\text { MEDA is currently collaborating with } \\
\text { other State MDAs, NGOs, Banks, and } \\
\text { IMOs to implement a number of } \\
\text { empowerment programmes. }\end{array}$ & $\begin{array}{l}\text { It is needful to have a policy framework } \\
\text { that connects the empowerment budget } \\
\text { of other State MDAs, the LGCs, NGOs, } \\
\text { and donors to MEDA's MDS. }\end{array}$ \\
\hline $\begin{array}{l}\text { GMED was sensitive to crosscutting } \\
\text { issues of gender, HIV/AIDS, } \\
\text { environment, and poverty reduction. }\end{array}$ & $\begin{array}{l}\text { MEDA is collaborating with other State } \\
\text { MDAs on women related empowerment } \\
\text { programmes. }\end{array}$ & $\begin{array}{l}\text { MEDA needs a holistic operational } \\
\text { framework that is sensitive to } \\
\text { crosscutting issues of gender, sanitation, }\end{array}$ \\
\hline
\end{tabular}




\begin{tabular}{|l|l|l|}
\hline & & and HIV/AIDS. \\
\hline $\begin{array}{l}\text { GMED partnered with innovators, } \\
\text { producers, and IMOs to develop } \\
\text { technologies in the supported } \\
\text { subsectors. }\end{array}$ & $\begin{array}{l}\text { MEDA is currently collaborating with the } \\
\text { Ministry of Science and Technology to } \\
\text { develop enterprise incubation centre for } \\
\text { the State. }\end{array}$ & $\begin{array}{l}\text { Guiding rules and platforms for } \\
\text { collaborations and partnerships R\&D is } \\
\text { needed to render MEDA more useful in } \\
\text { this regard. }\end{array}$ \\
\hline
\end{tabular}

In addition to the above lessons from India's GMED programme, MEDA in Cross River State needs also to take the following into consideration:

a. Include among the institutions eligible for BDS formal, semiformal and informal financial institutions.

b. Place special emphasis on support to small groups that include people from the lower segments of the population as owners or customers.

c. Support development of appropriate legal frameworks and regulation of self-reliant rural microfinance institutions (RMFIs) and self help groups (SHGs).

d. Provide incentives-driven schemes for upgrading IMOs and cooperatives in terms of legal status, supervision, and outreach.

e. Support the injection of equity into RMFIs for bridging, leveraging and upgrading purposes.

f. Do not support temporary or ad-hoc solutions with no chance of institutional sustainability.

\subsection{Study Area}

\section{Area Of Study And Methodology}

The study area, Calabar, the State Capital, is which composed of two Local Government Areas (LGAs), namely; Calabar South, and Calabar Municipality. Being contiguously located, both LGAs share common characteristics that may make differentiating them a bit difficult. The two LGAs are described briefly in the following sub-sections and, thereafter salient comparatives of the two LGAs are reported in Table 4.

\subsubsection{Calabar South}

Calabar South was carved out of the former Calabar Municipality in August 1991. It is bounded southwards by the Cross River estuary, which opens up to the Atlantic Ocean, and northwards by Calabar Municipality. The headquarters of the LGA is Anantigha. Its estimated population, 226,028 persons in 2012, was split almost equally between male and female. Calabar South represents about 6.63 percent of the State population. 40 percent of the population was in the age brackets $15-40$ years, and 74 percent was believed to be living below poverty line. Economic activities of the LGA were majorly wholesale and retail trade, vocational/technical occupations, and a variety of personal services. In the past, Calabar South earned notoriety for sundry criminal behaviours and impunities, but better policing and peace building have improve the security situation significantly, although the public perception of the Calabar South is yet to change significantly, as many still perceived that the LGA was unsafe. However, several enterprise owners still found excessive taxation and harassment by thugs popularly called 'area boys' quite disturbing.

Calabar South equally has a vast underground economy characterized by informal seafaring involving fishing, couriering of locally refined petroleum products, rice, used (or second hand) cloths, and timber. Operators within the underground economy are often chased around as criminals, as no effort is spared to distinguish "informal" but legitimate businesses from clear-cut criminal activities. Such wholesale criminalizing of the underground economy makes business formalization promotion more difficult. What obtains is that Government set up task forces to chase and apprehend the criminals, but such efforts often end in fiasco as task force members covertly protect the operators in exchange for informal monetary transfers.

\subsubsection{Calabar Municipality}

The city of Calabar assumed Municipal status in 1976. It covers an area of 161.44 square kilometres and the population projected to reach 250,000 by 2015. It is largely a Civil Service economy, but wholesale and retail trade, hotels and restaurants, personal services, subsistence crop cultivation, and commercial livestock and fisheries were common. Like Calabar South, the Municipality has a vast concentration of businesses, shops, markets, and street trading. However the level of business formalization seems much higher in the Municipality than in Calabar South. The seaport, airport, Nigeria's premier free trade zone (FTZ), and Tinapa Resort (which also has the status of a FTZ) are located in or around the Municipality.

Basically, the strategic development infrastructure listed above were generally underutilized. The seaport needs further dredging for large vessels to berth, and few Crossriverians were actively engaged in large scale import/export business. The runway in Calabar airport was too short to allow large airships to land or takeoff, and it had no cargo terminal for large consignment of good. The two FTZ were generally underutilized due largely to incapacities in the seaport and airport, weak local purchasing power, and poorly maintained roads that made movement of persons and goods to and from Calabar. Like in Calabar South, complaints of excessive taxation come from various business operators. 
Table 4 attempts to compare Calabar South and Calabar Municipality based on key characteristic like history, geography, socioeconomic milieu and environmental challenges.

Table 4: Key Characteristics of Calabar South and Calabar Municipality

\begin{tabular}{|c|c|}
\hline Calabar South & Calabar Municipality \\
\hline \multicolumn{2}{|l|}{ History } \\
\hline $\begin{array}{l}\text { Carved out of the former Calabar Municipality in August } \\
\text { 1991. Bounded southwards by the Cross River estuary which } \\
\text { opens up to the Atlantic Ocean, and northwards by the } \\
\text { Municipality. }\end{array}$ & $\begin{array}{l}\text { The city of Calabar assumed Municipal status in } 1976 . \\
\text { Bounded Southwards by Calabar South and Akpabuyo } \\
\text { LGAs, and Northwards by Odukpani and Akamkpa } \\
\text { LGAs }\end{array}$ \\
\hline \multicolumn{2}{|l|}{ Geography } \\
\hline $\begin{array}{l}\text { Lies largely within the mangrove freshwater drained by } \\
\text { rivers and streams, with a number of seaward communities. } \\
\text { The estimated population was } 226,028 \text { persons in } 2012 \text {, and } \\
\text { projected to reach } 245,550 \text { by year } 2015 \text {. }\end{array}$ & $\begin{array}{l}\text { Lies in the tropical rain forests. It covers an area of } \\
161.44 \text { square kilometres and population of } 179,392 \\
\text { people by } 2006 \text { (National Census), projected to reach } \\
250,000 \text { by } 2015 \text {. }\end{array}$ \\
\hline \multicolumn{2}{|l|}{ Socioeconomic Milieu } \\
\hline $\begin{array}{l}\text { An enlarging underground economy associated with informal } \\
\text { seafaring. There is need to change the perception that } \\
\text { Calabar South is unsafe. It is also needful to deal with } \\
\text { activities of hired tax/rate collectors and task forces. }\end{array}$ & $\begin{array}{l}\text { Underutilized key development infrastructure - seaport, } \\
\text { airport, Nigeria's premier FTZ, and Tinapa Resort and } \\
\text { Convention Centre - and growing challenges of urban } \\
\text { transportation need to be fixed with a suitable system of } \\
\text { mass transit. }\end{array}$ \\
\hline \multicolumn{2}{|l|}{ Environmental Issues } \\
\hline $\begin{array}{l}\text { Marine erosion and regular flooding threaten major streets } \\
\text { and strategic buildings. Growing vehicular road users posing } \\
\text { threats of air and noise pollution and holdups. Significant } \\
\text { slumming in the fringes of Anantigha, Ibesikpo, back of } \\
\text { Unical/CRUTECH, etc calls for reversion to planned } \\
\text { urbanization }\end{array}$ & $\begin{array}{l}\text { Landslides and erosion compounded by regular } \\
\text { flooding. Significant slumming in the fringes } \\
\text { particularly reclaimed new settlements around } \\
\text { Nyakasang, } 9^{\text {th }} \text { Miles, Ikot Effanga, and Mile } 8 \text { axes. } \\
\text { Growing vehicular road users posing threats of air and } \\
\text { noise pollution and holdups. }\end{array}$ \\
\hline
\end{tabular}

\subsection{Methodology}

This pilot survey collected and analyzed information obtained from 3660 randomly sampled enterprise owners/operators. As summarized in Table 5, 1654 respondents were from Calabar South, and 2006 from Calabar Municipality. The respondents from Calabar South were 52.06 percent male and 47.94 percent female, and 54.39 percent male and 45.61 percent female from Calabar Municipality. Overall, male respondents were 53.33 percent and female 46.67 percent. Information was collected by means of structured questionnaire and analyzed using simple percentages.

Table 5: Number of Respondents by Local Government Areas

\begin{tabular}{|l|l|l|l|l|l|l|}
\hline \multirow{2}{*}{ Gender } & Calabar South & Calabar Municipality & Total & Percent \\
\cline { 2 - 7 } & Number & Percent & Number & Percent & Number & Percis \\
\hline Male & 861 & 52.06 & 1091 & 54.39 & 1952 & 53.33 \\
\hline Temale & 793 & 47.94 & 915 & 45.61 & 1708 & 46.67 \\
\hline
\end{tabular}

\subsection{Study Objectives and Research Questions}

The study objectives and related research questions are summarized in Table 6.

Table 6: Study Objectives and Research Questions

\begin{tabular}{|c|c|}
\hline \multirow{7}{*}{$\begin{array}{l}\text { 1. To determine the } \\
\text { employees' preferences of } \\
\text { enterprises. }\end{array}$} & 1.1. Do enterprises have gender biases in selecting employees? \\
\hline & 1.2. What was the average number of employees of enterprises? \\
\hline & 1.3. What was the relative preference of enterprises for full time, part-time, and commission employees? \\
\hline & 1.4. Did the number of employees change in the last 3 years? \\
\hline & 1.5. What were the skill preferences of enterprises? \\
\hline & 1.6. How many Crossriverians did the enterprises employ? \\
\hline & 1.7. What was the spread of employees of Cross River State origin by professional cadre? \\
\hline \multirow{8}{*}{$\begin{array}{lr}2 . \quad \text { To describe } & \text { the } \\
\text { demographics } & \text { and } \\
\text { educational status } & \text { of } \\
\text { enterprise } & \\
\text { owners/operators. } & \end{array}$} & 2.1. What was the gender distribution of enterprise owners/operators? \\
\hline & 2.2. What were the languages spoken by enterprise owners/operators? \\
\hline & 2.3. What was the age distribution of enterprise owners? \\
\hline & 2.4. What was the marital status of enterprise owners? \\
\hline & 2.5. What was state of origin of enterprise owners/operators? \\
\hline & 2.6. What were the LGA of origin of enterprise owners/operators from CRS? \\
\hline & 2.7. What proportion of enterprise owners was physically challenged? \\
\hline & 2.8. What was the educational status of enterprise owners? \\
\hline \multirow{4}{*}{$\begin{array}{l}\text { 3.To define enterprise } \\
\text { types and sectors }\end{array}$} & 3.1. What was the distribution of enterprises by sector? \\
\hline & 3.2. What proportion of enterprises had branches? \\
\hline & 3.3. What proportion of enterprise was mobile or stationed? \\
\hline & 3.4. What was the distribution of enterprises by specific business activities? \\
\hline
\end{tabular}




\begin{tabular}{|c|c|}
\hline & 3.5. What were the proportion of sole proprietorships, partnerships, and limited liability? \\
\hline \multirow{9}{*}{$\begin{array}{l}\text { 4. To assess bankability of } \\
\text { enterprises. }\end{array}$} & 4.1. Percentage of enterprises with bank accounts. \\
\hline & 4.2. Enterprises major sources of venture capital. \\
\hline & 4.3. Enterprises with expansion plans. \\
\hline & 4.4. Enterprises willingness to obtain bank loans. \\
\hline & 4.5. Enterprises that obtained loans from banks before \\
\hline & 4.6. Factors that inhibit access to bank credit \\
\hline & 4.7. Enterprises that negotiated for project financing before. \\
\hline & 4.8. The banks enterprises do business with. \\
\hline & 4.9. Enterprise having websites/email address. \\
\hline \multirow{4}{*}{$\begin{array}{l}5 . \quad \text { To determine } \\
\text { enterprises' perception of } \\
\text { the tax system. }\end{array}$} & 5.1. Enterprise paying taxes to government. \\
\hline & 5.2. Rating of the tax system by enterprises. \\
\hline & 5.3. Aspects of the tax system enterprises would want changed. \\
\hline & 5.4. Adverse impact of taxes on profitability of enterprises. \\
\hline \multirow{4}{*}{$\begin{array}{l}6 . \quad \text { To assess the } \\
\text { accessibility of BDS by } \\
\text { enterprises }\end{array}$} & 6.1. Enterprise owners/operators with prior apprenticeship training/mentoring. \\
\hline & 6.2. Enterprise owners/operators that benefited from specific BDS programmes. \\
\hline & 6.3. Enterprises that received support from the LGCs. \\
\hline & 6.4. What enterprises require for improving their businesses. \\
\hline \multirow{3}{*}{$\begin{array}{l}\text { 7. To assess the level of } \\
\text { business formalization in } \\
\text { the State }\end{array}$} & 7.1. The registration status of enterprises. \\
\hline & 7.2. The ownership structure of enterprises. \\
\hline & 7.3. If not registered, what factors are responsible? \\
\hline \multirow{5}{*}{$\begin{array}{l}8 . \quad \text { To determine } \\
\text { growth prospects } \\
\text { enterprises }\end{array}$} & 8.1. Capital Base of enterprise. \\
\hline & 8.2. Capital base changed in the last 3 years? \\
\hline & 8.3. Overall profitability rating of enterprises \\
\hline & 8.4. Asset base changed in the last three years? \\
\hline & 6.5. Owners' perception of factors that affect enterprise growth \\
\hline
\end{tabular}

\subsection{Employees' Preferences of Enterprises}

\section{Discussion Of Findings}

The findings for research questions related to employees' preference of enterprises are in Table 7 and further summarized below:

a) Gender Preferences: Employers in both LGAs did not significant discriminate between male and female employees. This was quite understandable as the leading business activities - wholesale and retail trade and hairdressing/barbing - had minimal gender selectivity.

b) Number of Employees: Both LGAs had comparable number of microenterprises. Calabar Municipality had more small enterprises than Calabar South. Both had comparable number of medium and large enterprises.

c) Enterprises' Required Skills: Enterprises in Calabar Municipality required more technically skilled workers than those in Calabar South perhaps because there were more medium enterprises in the Municipality than in Calabar South. However, capacity building support programmes should generally be multifaceted and aimed at developing different skill areas required by enterprises.

d) Preferred employment types (i.e. full time, part-time, commission):Preference forfull time workers was higher in Calabar Municipality than in Calabar South. Equally, the combination of full and part time workers was higher in Calabar Municipality than in Calabar South.

e) Growth of employment in the last 3 years: majorityof respondents indicated either no growth or decline in employment. This can be explained by slow growth of economic activities. More specifically, the major businesses were in the services sectors, which generally create fewer jobs than processing. The employment situation in Calabar Municipality is more fluid than in Calabar South because the former had more employers indicating no growth and increased growth at the same time.

f) Employees of Cross River State origin: More Crossriverians were employed in enterprises located in Calabar Municipality than in Calabar South. Employees of Cross River State origin constituted less than 6 percent of total employment in 70 percent of the enterprises interviewed. It is needful to render Crossriverians more employable with requisite skills and entrepreneurial culture, and enactment of Active Labour Market Policies (ALMPs) that offer incentives for enterprises employing more Crossriverians.

g) Crossriverians employees by professional/official cadre: In both Calabar Municipality and Calabar South, majority of Crossriverians employed were mainly in the lower cadre and causal labour category. Educational policy should focus on promoting the study of sciences, engineering, and other courses/professions that would increase the number belong to the high tech cadre. 
Table 7: Employees' Preferences of Enterprises

\begin{tabular}{|c|c|c|c|}
\hline $\begin{array}{l}\text { Research } \\
\text { Indicator }\end{array}$ & $\begin{array}{l}\text { Survey Findings - Calabar } \\
\text { South }\end{array}$ & $\begin{array}{l}\text { Survey Findings - Calabar } \\
\text { Municipality }\end{array}$ & Implications of Findings \\
\hline $\begin{array}{l}\text { 1.1. Employers } \\
\text { gender } \\
\text { preferences }\end{array}$ & $\begin{array}{l}57.2 \% \text { preferred female to male } \\
\text { employees, } 32.0 \% \text { preferred } \\
\text { male to female employees, and } \\
10.8 \% \text { percent were indifferent. }\end{array}$ & $\begin{array}{l}56.1 \% \text { preferred female to } \\
\text { male employees, } 29.4 \% \\
\text { preferred male to female } \\
\text { employees, and } 14.5 \% \text { percent } \\
\text { were indifferent. }\end{array}$ & $\begin{array}{l}\text { Employers in both LGAs did not } \\
\text { significant discriminate between } \\
\text { male and female employees. }\end{array}$ \\
\hline $\begin{array}{lr}1.2 . & \text { Average } \\
\text { number } & \text { of } \\
\text { employees } & \end{array}$ & $\begin{array}{l}49.7 \% \text { of enterprises had } 5 \text { or } \\
\text { less number of employees, } \\
37.4 \% \text { had } 6-49 \text { employees, } \\
8.4 \% \text { had } 50-199 \text { employees, } \\
\text { and } 4.5 \% \text { had above } 200 \\
\text { employees. }\end{array}$ & $\begin{array}{l}47.6 \% \text { of enterprises had } 5 \text { or } \\
\text { less number of employees, } \\
40.5 \% \text { had } 6-49 \text { employees, } \\
7.2 \% \text { had } 50-199 \text { employees, } \\
\text { and } 4.7 \% \text { had above } 200 \\
\text { employees. }\end{array}$ & $\begin{array}{l}\text { Both LGs had comparable number } \\
\text { of microenterprises. Calabar } \\
\text { Municipality had more small } \\
\text { enterprises than Calabar South. } \\
\text { Both had comparable number of } \\
\text { medium and large enterprises. }\end{array}$ \\
\hline $\begin{array}{l}\text { 1.3. The skills } \\
\text { enterprises } \\
\text { require for more } \\
\text { productivity }\end{array}$ & $\begin{array}{l}58.2 \% \text { technical/engineering } \\
\text { skills, } 19.1 \% \text { marketing skills, } \\
18.5 \% \text { financial management } \\
\text { skills, and } 4.4 \% \text { multiple skilled } \\
\text { employees }\end{array}$ & $\begin{array}{l}56.7 \% \text { technical/engineering } \\
\text { skills, } 19.9 \% \text { marketing skills, } \\
18.4 \% \text { financial management } \\
\text { skills, and } 5.0 \% \text { multiple } \\
\text { skilled }\end{array}$ & $\begin{array}{l}\text { Calabar Municipality required more } \\
\text { technically skilled workers than } \\
\text { Calabar South perhaps because it } \\
\text { had more medium enterprises. }\end{array}$ \\
\hline $\begin{array}{l}\text { 1.4. Preferred } \\
\text { employment } \\
\text { types, i.e. full } \\
\text { time, part-time, } \\
\text { commission }\end{array}$ & $\begin{array}{l}69.8 \% \text { had full time employees, } \\
14.8 \% \text { had part time employees, } \\
\text { and } 15.4 \% \text { had commissioned } \\
\text { employment. }\end{array}$ & $\begin{array}{l}78.9 \% \text { had full time } \\
\text { employees, } 8.3 \% \text { had part } \\
\text { time employees, and } 12.8 \% \\
\text { had both full time and part } \\
\text { time employees }\end{array}$ & $\begin{array}{l}\text { There is higher preference of full } \\
\text { time workers in Calabar } \\
\text { Municipality, and preference for } \\
\text { combination of full and part time } \\
\text { workers is higher in Calabar } \\
\text { Municipality. }\end{array}$ \\
\hline $\begin{array}{l}\text { 1.5. Growth of } \\
\text { employment in } \\
\text { the last } 3 \text { years }\end{array}$ & $\begin{array}{l}62.8 \% \text { indicated no growth in } \\
\text { employment in the last } 3 \text { years, } \\
27.4 \% \text { had growth in } \\
\text { employment, while } 9.8 \% \\
\begin{array}{l}\text { experienced decline } \\
\text { employment }\end{array} \\
\end{array}$ & $\begin{array}{l}63.3 \% \text { indicated no growth in } \\
\text { employment in the last } 3 \\
\text { years, } 28.6 \% \text { had growth in } \\
\text { employment, while } 8.1 \% \\
\text { experienced decline in } \\
\text { employment }\end{array}$ & $\begin{array}{l}\text { The employment situation in } \\
\text { Calabar Municipality is more fluid } \\
\text { than in Calabar South because the } \\
\text { former had more employers } \\
\text { indicating no growth and increased } \\
\text { growth at the same time. }\end{array}$ \\
\hline $\begin{array}{l}\text { 1.6. Employees } \\
\text { of Cross River } \\
\text { State origin }\end{array}$ & $\begin{array}{l}9.7 \% \text { of enterprises employed } \\
\text { less than } 5 \% \text { Crossriverians, } \\
76.3 \% \text { employed } 5 \%-20 \% \text {. } \\
14.0 \% \text { had over } 20--50 \% \text {; } \\
\text { Overall, } 44.1 \% \text { had over } 50 \% \text { of } \\
\text { employees of Cross River State } \\
\text { origin. }\end{array}$ & $\begin{array}{l}12.1 \% \text { of } \\
\text { employed less than } 5 \% \\
\text { Crossriverians, } \\
\text { employed } 5 \%-20 \% .5 \% \\
\text { had over } 20--50 \% ; \text { Overall, } \\
49.3 \% \text { had over } 50 \% \text { of } \\
\text { employees of Cross River } \\
\text { State origin. }\end{array}$ & $\begin{array}{l}\text { More Crossriverians were } \\
\text { employed in enterprises located in } \\
\text { Calabar Municipality than in } \\
\text { Calabar South. }\end{array}$ \\
\hline $\begin{array}{l}\text { 1.7. Crossriverian } \\
\text { employees by } \\
\text { professional/offic } \\
\text { ial cadre }\end{array}$ & $\begin{array}{l}35.3 \% \text { of } \\
\text { employed were in the lower } \\
\text { cadre, } 26.3 \% \text { were causal } \\
\text { labour, } 18.7 \% \text { were in } \\
\text { managerial cadre, and } 19.7 \% \\
\text { were in high-tech cadre. }\end{array}$ & $\begin{array}{l}34.9 \% \text { of } \begin{array}{l}\text { Crossriverians } \\
\text { employed were in the lower }\end{array} \\
\text { cadre, } 29.8 \% \text { were causal } \\
\text { labour, } 18.7 \% \text { were in } \\
\text { managerial cadre, and } 16.6 \% \\
\text { were in high-tech cadre. }\end{array}$ & $\begin{array}{l}\text { In both Calabar Municipality and } \\
\text { Calabar South, the Crossriverians } \\
\text { employed were more in the lower } \\
\text { cadre and causal labour category. }\end{array}$ \\
\hline
\end{tabular}

\subsection{Demographic Characteristics and Educational Status of Enterprise Owners/Operators.}

Details of the research questions, relevant findings, and implications of the findings are in Table 8 and further summarized below:

a) Gender characteristics of enterprise owners: Male owned businesses were more than female owned enterprises in both Calabar Municipality and Calabar South This may not be entirely true because several women who indeed own enterprises would prefer that the public see them as belonging to their hubbies.

b) Languages spoken by enterprise owners: English, Pidgin English, and Efik/Ibibo were commonly spoken in both LGAs. Printing information, education, and communication (IEC) materials in English language and Pidgin English would be economical and effective.

c) Age distribution of enterprise owners: Majority of enterprise owners in Calabar South and Calabar Municipality were in the age brackets $25-45$ years. This provides ample opportunities for their training and reorientation with resultant improvement in productivity.

d) Marital Status of enterprise owners: There were more married enterprise owners in Calabar Municipality than in Calabar South. Majority of enterprise owners were married, and possibly had direct dependants. Additional dependency often comes from extended family members.

e) State of origin of enterprise owners: Calabar Municipality had more indigenous enterprise owners than Calabar South. The percentage of enterprise owners from Akwa Ibom and South East States origin were high in both LGAs.

f) Enterprise owners LGA of Origin: Enterprise owners of CRS origin in the 2 LGAs were largely from the South Senatorial Zone. Upgrading infrastructures in Ikom and Ogoja should promote agglomeration of new enterprises by the indigenes of composite LGAs in the Central and North Senatorial Zones respectively. 
g) Physically challenged enterprise owners: More enterprise owners indicated being physically challenged in Calabar Municipality than in Calabar South. But generally, fewer enterprises indicated being physically challenged, and there is likelihood that the number of physically challenged persons could have been more, but admitting being physically challenged may be considered derogatory.

h) Educational status of enterprise owners: Calabar Municipality had higher percentage of B.Sc/HND holders than Calabar South. Clearly, majority of enterprise owners were literate, having had secondary school education, and potentially trainable.

Table 8: Demographics Characteristics and Educational Status of Enterprise Owners/Operators

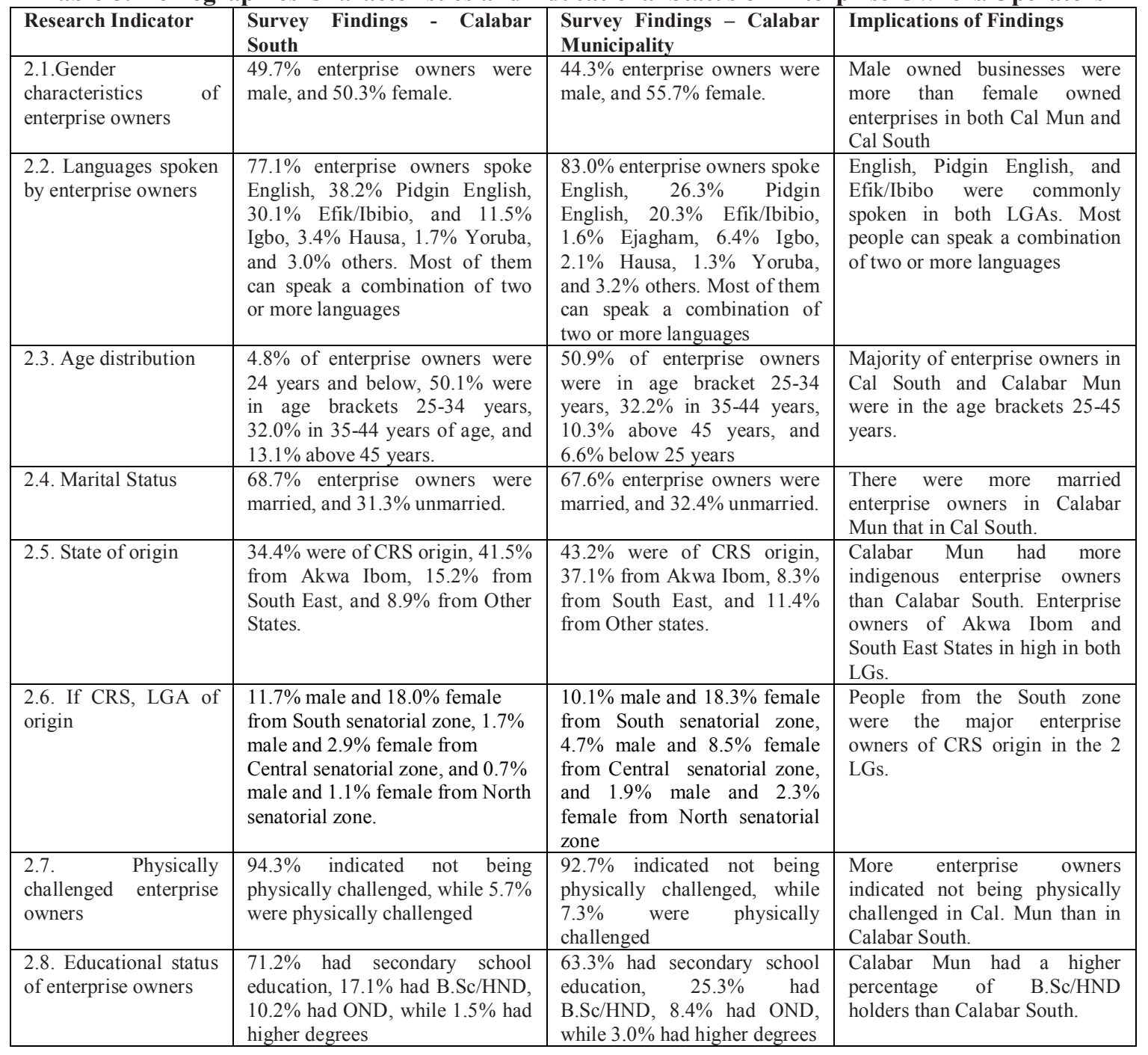

\subsection{Enterprise Type and Sector}

Specific research questions on enterprise types and sectors, survey findings, and the implications of findings are contain in Table 9, and further summarized below:

a) Distribution of enterprises by sector: More enterprises were in wholesale and retail trade and other services in both LGAs. Involvement in manufacturing/processing was low in both LGAs.

b) Enterprises having branches: More enterprises in Calabar Municipality had branches than in Calabar South. But overall there were fewer enterprises with branches indicating, possibly, slow enterprise growth and poor market penetration.

c) Mobile and stationed enterprises: More enterprises in both LGAs were stationed businesses with known addresses, that could be revisited and information obtained can be used to update the database of MEDA.

d) Registration types: Fewer enterprises were partnerships and limited liability concerns, which indicated slower rate of structural transformation from microenterprise to large limited liability concerns. Policy needs to promote establishment of more partnerships and limited liability companies. 
e) Specific Business activities of sole proprietors: Wholesale \& retail trade and hairdressing/.barbing were leading microenterprises in both Calabar Municipality and Calabar South.

Table 9: Enterprise Type and Sector

\begin{tabular}{|c|c|c|c|}
\hline Research Indicator & $\begin{array}{l}\text { Survey Findings - Calabar } \\
\text { South }\end{array}$ & $\begin{array}{l}\text { Survey Findings }- \text { Calabar } \\
\text { Municipality }\end{array}$ & Implications of Findings \\
\hline $\begin{array}{l}\text { 3.1. Distribution of } \\
\text { enterprises by sector }\end{array}$ & $\begin{array}{l}54.0 \% \text { were in other services, } \\
47.3 \% \text { in wholesale and retail } \\
\text { trade, } 4.0 \% \text { in manufacturing, } \\
0.3 \% \text { in oil \& gas, } 0.1 \% \text { in } \\
\text { agriculture, and } 0.2 \% \text { in solid } \\
\text { minerals. Some enterprises were } \\
\text { operating in two or more } \\
\text { sectors. }\end{array}$ & $\begin{array}{l}56.4 \% \text { were in other services, } \\
44.4 \% \text { in wholesale and retail } \\
\text { trade, } 3.3 \% \text { in manufacturing, } \\
0.5 \% \text { in oil \& gas, } 0.4 \% \text { in } \\
\text { agriculture, and } 0 \% \text { in solid } \\
\text { minerals. Some enterprises were } \\
\text { operating in two or more sectors. }\end{array}$ & $\begin{array}{l}\text { The distribution of enterprise } \\
\text { owners for both LGAs } \\
\text { indicated more in other } \\
\text { services and trade and less in } \\
\text { manufacturing. Some } \\
\text { enterprises were operating in } \\
\text { two or more sectors } \\
\text { simultaneously. }\end{array}$ \\
\hline $\begin{array}{l}\text { 3.2. Enterprises having } \\
\text { branches }\end{array}$ & $\begin{array}{l}60.1 \% \text { enterprises had no } \\
\text { branches, } 33.6 \% \text { had } 1-5 \\
\text { branches, } 4.7 \% \text { had } 6-10 \\
\text { branches, and } 1.6 \% \text { had above } \\
10 \text { branches. }\end{array}$ & 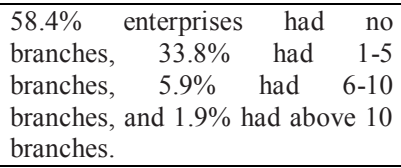 & $\begin{array}{l}\text { More enterprises in Calabar } \\
\text { Mun had branches than in Cal } \\
\text { South. }\end{array}$ \\
\hline $\begin{array}{l}\text { 3.5. Specific Business } \\
\text { activities of sole } \\
\text { proprietors. }\end{array}$ & $\begin{array}{l}\text { Wholesale/retail trade } 1^{\text {st }} \text {, } \\
\text { Tailors/fashion designers } 2^{\text {nd }} \text {, } \\
\text { hairdressing/barbing } 3^{\text {rd }} \text {, hotel } \& \\
\text { restaurants } 4^{\text {th }} \text {. }\end{array}$ & $\begin{array}{l}\text { Wholesale/retail trade } 1^{\text {st }} \text {, } \\
\text { hairdressing/barbing } 2^{\text {nd }} \text {, and hotel } \\
\& \text { restaurants } 3^{\text {rd }} \text {. Tailors/fashion } \\
\text { designers } 4^{\text {th }}\end{array}$ & $\begin{array}{l}\text { Wholesale\& retail trade and } \\
\text { hairdressing/.barbing were } \\
\text { leading microenterprises in } \\
\text { both Calalabar Mun and Cal } \\
\text { South. }\end{array}$ \\
\hline
\end{tabular}

Table 10 provided detailed statistics on specific business activities of sole proprietorships (majorly microenterprises) in both Calabar South and Calabar Municipality. Generally, fewer enterprises were engaged in carpentry/furniture, typing/computer operators, printing/publishing, electrical/electronic repairs, laundry services, and motor spare parts dealership, while more majority enterprises were engaged in wholesale and retail trade and hairdressing/barbing.

Table 10: Specific Business Activities of Sole Proprietors (majorly microenterprises)

\begin{tabular}{|c|c|c|c|c|}
\hline \multirow[b]{2}{*}{ Sole Proprietorships } & \multicolumn{2}{|c|}{ Calabar South } & \multicolumn{2}{|c|}{ Calabar Municipality } \\
\hline & Percentage & Ranking & Percentage & Ranking \\
\hline Wholesale/retail trade & $23 \%$ & $1^{\text {st }}$ & $30 \%$ & $1^{\mathrm{st}}$ \\
\hline carpentry/furniture & $1 \%$ & $4^{\text {th }}$ & $0 \%$ & \\
\hline Typing/computer operator & $1 \%$ & $4^{\text {th }}$ & $1 \%$ & $5^{\text {th }}$ \\
\hline Printing and publishing & $1 \%$ & $4^{\text {th }}$ & $0 \%$ & \\
\hline Aluminum works & $0 \%$ & & $0 \%$ & \\
\hline Electrical/electronic repairs & $1 \%$ & $4^{\text {th }}$ & $1 \%$ & $5^{\text {th }}$ \\
\hline GSM/digital equipment repairers & $1 \%$ & & $1 \%$ & $5^{\text {th }}$ \\
\hline Hairdressing/Barbing & $4 \%$ & $2^{\text {nd }}$ & $6 \%$ & $2^{\text {nd }}$ \\
\hline Pharmacy/drugs & $1 \%$ & $4^{\text {th }}$ & $1 \%$ & $5^{\text {th }}$ \\
\hline Motor Mechanics & $0 \%$ & & $0 \%$ & \\
\hline Welding/plumbing/fitting & $0 \%$ & & $0 \%$ & \\
\hline Generators repairs & $0 \%$ & & $0 \%$ & \\
\hline Hotels \& restaurants & $2 \%$ & $3^{\text {rd }}$ & $4 \%$ & $3^{\text {rd }}$ \\
\hline Tailors/fashion designers & $4 \%$ & $2^{\text {nd }}$ & $3 \%$ & $4^{\text {th }}$ \\
\hline Laundry services & $1 \%$ & $4^{\text {th }}$ & $1 \%$ & $5^{\text {th }}$ \\
\hline Spare part dealer & $1 \%$ & $4^{\text {th }}$ & $0 \%$ & \\
\hline Wood carving/art work/gift items & $0 \%$ & & $0 \%$ & \\
\hline Other services & $2 \%$ & $3^{\text {rd }}$ & $1 \%$ & $5^{\text {th }}$ \\
\hline
\end{tabular}

\subsection{Bankability of Enterprises}

Details of findings on bankability of enterprises are contained in Table 11 and further summarized below:

a) Enterprises having bank accounts: A large number of enterprises in both LGAs did not have functional bank accounts. Having functional bank accounts is promotes bankability. 
b) Enterprises' sources of venture capital: Majority of enterprise owners in both LGAs sourced venture capital from own savings and family members. Providing sub strategies for ensuring access to affordable credit should be an important component of BDS in the State.

c) Enterprises having expansion plans: 83.5 percent indicated having expansion plan. But it was doubtful if the expansion plans were credible and achievable judged by the low level of bankability, and slow pace of structural transformation among enterprises.

d) Willingness to obtain bank loans: No significant variation in both LGAs. Interest charges and ignorance were leading factors. It is needful to create a basket fund and network of microfinance for ensuring accessibility of affordable loans to enterprise owners.

e) Borrowing history of enterprises: Majority of enterprises in both LGAs had not obtained loans before. It is needful to institute an innovative micro-financing strategy for inclusion of microenterprises in the formal banking system, while shielding banks from risks of default.

f) Factors that inhibit access to bank credit: "No collaterals" and "ignorance" were leading factors inhibiting access to bank credit in both LGAs. Training and credit information dissemination will ameliorate demand side constraints, while effective collaboration and buy in of banks will ease supply side constraints.

g) Project financing competency of enterprises: Few enterprise owners negotiated for project financing in both LGAs. This generally suggested the need to develop a robust institutional framework and market for project financing.

h) Types of banks enterprises do business with: Majority of enterprises in both LGAs patronized commercial banks, and only a few did business with industry and agriculture bank. There is need to develop mechanisms for distributing information to enterprises on lending opportunities offered by the specialized banks and other lending agencies.

i) Enterprise having websites/email address: More enterprises in both LGAs did not have websites/email addresses. Educating enterprises on how to own and use email addresses and websites should be a critical human capacity development component of MEDA's MDS.

Table 11: Bankability of Enterprises

\begin{tabular}{|c|c|c|c|}
\hline Research Indicator & $\begin{array}{l}\text { Survey Findings }- \text { Calabar } \\
\text { South }\end{array}$ & $\begin{array}{l}\text { Survey Findings }- \text { Calabar } \\
\text { Municipality }\end{array}$ & Implications of Findings \\
\hline $\begin{array}{l}\text { 4.1. Enterprises } \\
\text { having bank accounts }\end{array}$ & $\begin{array}{l}73.6 \% \text { had bank accounts, while } \\
26.4 \% \text { did not have bank accounts }\end{array}$ & $\begin{array}{l}73.3 \% \text { had bank accounts, while } \\
26.7 \% \text { did not have bank accounts }\end{array}$ & $\begin{array}{l}\text { A large number of enterprises in } \\
\text { both LGs did not have } \\
\text { functional bank accounts. }\end{array}$ \\
\hline $\begin{array}{ll}4.2 . & \text { Enterprises' } \\
\text { sources } & \text { of venture } \\
\text { capital } & \end{array}$ & $\begin{array}{l}83.3 \% \text { from own saving, } 17.8 \% \\
\text { from family members, } 6.8 \% \text { from } \\
\text { "settlements" of their masters, } \\
\text { and } 4.1 \% \text { from banks. }\end{array}$ & $\begin{array}{l}72.4 \% \text { from own saving, } 18.1 \% \\
\text { from family members, } 5.1 \% \text { from } \\
\text { "settlements" of their masters, and } \\
4.4 \% \text { from banks. }\end{array}$ & $\begin{array}{l}\text { Majority of enterprise owners in } \\
\text { both LGs sourced venture } \\
\text { capital from own savings and } \\
\text { family members. }\end{array}$ \\
\hline $\begin{array}{lr}4.3 . & \text { Enterprises } \\
\text { having } & \text { expansion } \\
\text { plans } & \\
\end{array}$ & $\begin{array}{l}84.0 \% \text { had expansion plan, } 13.3 \% \\
\text { did not have, while } 2.7 \% \text { were } \\
\text { uncertain. }\end{array}$ & $\begin{array}{l}82.5 \% \text { had expansion plan, } 16.7 \% \\
\text { did not have, while } 0.8 \% \text { were } \\
\text { uncertain. }\end{array}$ & $\begin{array}{l}\text { Majority of enterprises in both } \\
\text { LGAs had expansion plan. }\end{array}$ \\
\hline $\begin{array}{l}\text { 4.4. Factors that } \\
\text { affect attitude to } \\
\text { seeking bank lending }\end{array}$ & $\begin{array}{l}46.5 \% \text { interest rate, } 29.6 \% \text { fear of } \\
\text { default, } 12.5 \% \text { lengthy processes, } \\
11.4 \% \text { hated borrowing. }\end{array}$ & $\begin{array}{l}47.5 \% \text { interest rate, } 26.9 \% \text { fear of } \\
\text { default, } 13.9 \% \text { lengthy processes, } \\
11.7 \% \text { hated borrowing. }\end{array}$ & $\begin{array}{l}\text { No significant variation in } \\
\text { responses of respondents for } \\
\text { this question. Interest charges } \\
\text { and ignorance of how loans can } \\
\text { assist businesses were leading } \\
\text { factors }\end{array}$ \\
\hline $\begin{array}{l}\text { 4.5. Enterprises have } \\
\text { obtained loans from } \\
\text { banks before }\end{array}$ & $\begin{array}{l}83.7 \% \text { enterprise had not obtained } \\
\text { loans before, while } 16.3 \% \text { had } \\
\text { obtained loans }\end{array}$ & $\begin{array}{l}85.6 \% \text { enterprise had not obtained } \\
\text { loans before, while } 14.4 \% \text { had } \\
\text { obtained loans }\end{array}$ & $\begin{array}{l}\text { Majority of enterprises in both } \\
\text { LGs did not obtain loans before. }\end{array}$ \\
\hline $\begin{array}{l}\text { 4.6. Factors that } \\
\text { inhibit access to bank } \\
\text { credit }\end{array}$ & $\begin{array}{l}\text { No collaterals } 36.9 \% \text {, ignorance } \\
29.9 \% \text {, lending policies } 25.6 \% \text {, } \\
\text { and poor proposals } 7.6 \% \text {. }\end{array}$ & $\begin{array}{l}\text { No collaterals } 43.9 \% \text {, ignorance } \\
33.3 \% \text {, lending policies } 14.5 \% \text {, and } \\
\text { poor proposals } 8.3 \% \text {. }\end{array}$ & $\begin{array}{l}\text { No collaterals and ignorance } \\
\text { were leading factors affecting } \\
\text { access to bank credit in both } \\
\text { LGs. }\end{array}$ \\
\hline $\begin{array}{l}\text { 4.7. Negotiated for } \\
\text { project financing } \\
\text { before? }\end{array}$ & $\begin{array}{l}79.3 \% \text { not negotiated for project } \\
\text { financing, } 20.7 \% \text { negotiated }\end{array}$ & $\begin{array}{l}84.7 \% \text { not negotiated for project } \\
\text { financing, } 15.3 \% \text { negotiated. }\end{array}$ & $\begin{array}{l}\text { Few enterprises owners } \\
\text { negotiated for project financing } \\
\text { in both LGs. }\end{array}$ \\
\hline $\begin{array}{l}\text { 4.8. Types of banks } \\
\text { enterprises } \\
\text { business with }\end{array}$ & $\begin{array}{l}54.9 \% \text { commercial banks, } 21.1 \% \\
\text { microfinance banks, } 5.6 \% \\
\text { industry bank, and } 6.4 \% \\
\text { agriculture bank. However, } 12.0 \% \\
\text { are not doing business with any } \\
\text { bank }\end{array}$ & $\begin{array}{l}52.3 \% \text { commercial banks, } 21.8 \% \\
\text { microfinance banks, } 6.9 \% \text { industry } \\
\text { bank, and } 5.7 \% \text { agriculture bank. } \\
\text { However, } 13.3 \% \text { are not doing } \\
\text { business with any bank }\end{array}$ & $\begin{array}{l}\text { Majority of enterprises in both } \\
\text { LGAs patronized commercial } \\
\text { banks, and only a few did } \\
\text { business with industry and } \\
\text { agriculture bank. }\end{array}$ \\
\hline $\begin{array}{l}\text { 4.9. Enterprise having } \\
\text { websites/email } \\
\text { address }\end{array}$ & 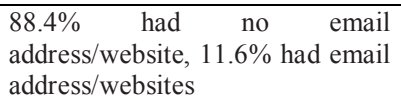 & $\begin{array}{lrcr}84.6 \% & \text { had } & \text { no } & \text { email } \\
\text { address/website, } & 15.4 \% \text { had } & \text { email } \\
\text { address/websites } & & & \\
\end{array}$ & $\begin{array}{l}\text { More enterprises in both LGs } \\
\text { did not have websites/email } \\
\text { addresses. }\end{array}$ \\
\hline
\end{tabular}




\subsection{Accessibility of BDS Services by Enterprises}

Data collected on accessibility of BDS services by enterprises is provided in Table 12 and summarized further below:

a. Enterprise owners had prior apprenticeship training/mentoring:Majority of enterprise owners in both LGAs had no prior apprenticeship training or mentoring. Apprenticeship and mentoring should be essential aspects of human capacity development.

b. Enterprise owners benefited from specific BDS programme:Most enterprise owners in both LGAs did not benefit from any form of BDS. MEDA's BDS should be all inclusive and able to accommodate eligible microenterprises and prospective entrepreneurs.

c. Enterprises receiving support from the LGCs: Majority of enterprises in both LGAs perceived that support from the LGs was poor MEDA needs to partner more effectively with the Local Government Councils (LGCs) to take microenterprise development down to the grassroots.

d. What will improve the business of enterprises: In both LGAs cheaper loans and secure markets were what enterprises required to improve their businesses. Detailed industry specific enquiries were needed to determine the incentives and support required in different industries and sectors.

Table 12: Accessibility of BDS Services by Enterprises

\begin{tabular}{|c|c|c|c|}
\hline Research Indicator & $\begin{array}{l}\text { Survey Findings - Calabar } \\
\text { South }\end{array}$ & $\begin{array}{l}\text { Survey Findings } \\
\text { Calabar Municipality }\end{array}$ & Implications of Findings \\
\hline $\begin{array}{l}5.1 . \text { Owner(s) had prior } \\
\text { apprenticeship/mentoring } \\
\text { training }\end{array}$ & $\begin{array}{l}71.7 \% \text { did not have, } 28.3 \% \\
\text { had. }\end{array}$ & $\begin{array}{l}63.5 \% \text { did not have, } \\
36.5 \% \text { had. }\end{array}$ & $\begin{array}{l}\text { Majority of enterprise owners in both } \\
\text { LGAs had no prior apprenticeship } \\
\text { training/mentoring. }\end{array}$ \\
\hline $\begin{array}{l}\text { 5.2. Owner(s) benefited from } \\
\text { specific BDS programmed }\end{array}$ & $\begin{array}{l}\text { From MEDA } 4.7 \% \text {, Other } \\
\text { MDAs } 2.3 \% \text {, Others } 4.4 \% \text {, } \\
\text { LGCs } 1.6 \% \text {, cooperatives } \\
2.9 \% \text {, Donors } 1.1 \%\end{array}$ & 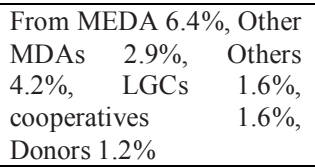 & $\begin{array}{l}\text { Most enterprise owners in both LGAs } \\
\text { did not benefit from any form of BDS. }\end{array}$ \\
\hline 5.3. Supp & $\begin{array}{l}\text { Modest } 12.9 \% \text {, indifferent } \\
10.2 \% \text {, poor } 69.0 \% \text {, and } \\
\text { hostile } 7.9 \% \text {. }\end{array}$ & $\begin{array}{l}\text { Modest } 10.5 \%, \\
\text { indifferent } 8.0 \% \text { poor } \\
74.5 \% \text {, and hostile } 7.0 \% \text {. }\end{array}$ & $\begin{array}{l}\text { Majority of enterprises in both LGAs } \\
\text { perceived that support from the LGs } \\
\text { was poor. }\end{array}$ \\
\hline $\begin{array}{l}\text { 5.4. What enterprises require } \\
\text { to improve their business }\end{array}$ & $\begin{array}{l}59.1 \% \text { tax incentives, } 74.8 \% \\
\text { cheaper loans, } 81.1 \% \\
\text { secured markets, } 52.3 \% \\
\text { machinery, and } 22 \% \text { eased } \\
\text { access to land. }\end{array}$ & $\begin{array}{l}56.6 \% \text { tax incentives, } \\
61.0 \% \text { cheaper loans, } \\
72.4 \% \\
\text { markets, } 41.7 \% \text { secured } \\
\text { machinery, and } 24 \% \\
\text { eased access to land. }\end{array}$ & $\begin{array}{l}\text { In both LGAs cheaper loans and secure } \\
\text { markets were what enterprises required } \\
\text { to improve their businesses. }\end{array}$ \\
\hline
\end{tabular}

\subsection{The Level of Business Formalization}

Data collected on business formalization are contained in Table 13 and further summarized below:

a) Registration status of enterprises: Several enterprises indicated registering as sole proprietorships in both LGs, but a significant number were not registered. More education is required to update enterprise owners with information on how registration with CAC had become much easier.

b) Factors that inhibit enterprise registration:Owners of unregistered businesses indicated lack of finance as leading factor. It is needful to institute incentives targeted at encouraging more people to formalize their businesses.

Table 13: Level of Business Formalization

\begin{tabular}{|l|l|l|l|}
\hline Research Indicator & $\begin{array}{l}\text { Survey Findings - Calabar } \\
\text { South }\end{array}$ & $\begin{array}{l}\text { Survey Findings - Calabar } \\
\text { Municipality }\end{array}$ & Implications of Findings \\
\hline $\begin{array}{l}\text { 6.1. The registration } \\
\text { status of enterprises }\end{array}$ & $\begin{array}{l}15.4 \% \text { not registered, 0.8\% was } \\
\text { limited liability, 2.4\% was } \\
\text { partnership, and 81.4\% sole } \\
\text { proprietorships }\end{array}$ & $\begin{array}{l}\text { limited liability, 2.8\% was } \\
\text { partnership, and } 86.7 \% \text { sole } \\
\text { proprietorships }\end{array}$ & $\begin{array}{l}\text { Several enterprises } \\
\text { registering as sole proprietorships } \\
\text { in both LGA, but a significant } \\
\text { number were not registered. }\end{array}$ \\
\hline $\begin{array}{l}\text { 6.2. If not registered, } \\
\text { what factors are } \\
\text { responsible? }\end{array}$ & $\begin{array}{l}\text { Absence of incentives 27.1\%, } \\
\text { lack of finance 42.8\%, } \\
\text { information 17.7\%, fear of } \\
\text { taxation 12.4\%. }\end{array}$ & $\begin{array}{l}\text { Absence of incentives 27.5\%, of finance 45.8\%, } \\
\text { lackformation 15\%, fear of } \\
\text { taxation } 11.7 \% .\end{array}$ & $\begin{array}{l}\text { Onners of unregistered businesses } \\
\text { indicated lack of finance as leading } \\
\text { factor. }\end{array}$ \\
\hline
\end{tabular}

\subsection{Growth Prospects of Enterprises}

Information collected on growth prospects of enterprises are detailed in Table 14 and further summarized below: a) Capital Base of enterprise: Microenterprises were the leading businesses in the two LGAs, implying that microenterprise development should be the key component of BDS in the State.

b) Change in the capital base of enterprises in the last 3 years: A significant number of enterprise owners indicated that their capital base either improved or remained static in both LGAs. Encouraging 
enterprises to form and manage IMOs effectively and efficiently will enhance their chances of accessing funds, and promoting partnerships and collaborations that may lead to formation of larger enterprises.

c) Overall profitability rating of enterprises: Majority of enterprise owners in both LGAs indicated that they barely were able to break even. Zero or negative profit margin is a disincentive to business generally.

d) Change in asset base of enterprises in the last three years: More enterprises in both LGAs indicated that asset base either improved marginally or was static. Collaborating with the relevant IMOs to centrally provide machineries and equipments for use jointly by a group of enterprises providing similar services could wedge productivity loses associated with asset deficits.

e) Owners' perception of factors that affect enterprise growth: Majority of enterprise owners in both LGAs indicated that their profit margin is near zero. Low purchasing power and insecurity significantly inhibited enterprise growth. More enterprises would want to go into mass production if it is certain that they can sell products at prices that offered reasonable profits.

Table 14: Growth Prospects of Enterprises

\begin{tabular}{|c|c|c|c|}
\hline Research Indicator & $\begin{array}{l}\text { Survey Findings - Calabar } \\
\text { South }\end{array}$ & $\begin{array}{l}\text { Survey Findings - Calabar } \\
\text { Municipality }\end{array}$ & Implications of Findings \\
\hline $\begin{array}{l}\text { 7.1. Capital Base of } \\
\text { enterprise }\end{array}$ & $\begin{array}{l}87.5 \% \text { had less than N5 } \\
\text { million, } 6.7 \% \text { had between } \\
\mathrm{N} 5 \mathrm{~m} \text { and } \mathrm{N} 50 \mathrm{~m}, 4.8 \% \text { had } \\
\text { between } \mathrm{N} 50 \mathrm{~m} \text { and } \mathrm{N} 500 \mathrm{~m} \text {, } \\
\text { and } 1.0 \% \text { had above } \\
\text { N500m. }\end{array}$ & $\begin{array}{l}87.5 \% \text { had less than } \mathrm{N} 5 \\
\text { million, } 9.7 \% \text { had between } \\
\mathrm{N} 5 \mathrm{~m} \text { and } \mathrm{N} 50 \mathrm{~m}, 2 \% \text { had } \\
\text { between } \mathrm{N} 50 \mathrm{~m} \text { and } \mathrm{N} 500 \mathrm{~m} \text {, } \\
\text { and } 0.8 \% \text { had above } 500 \mathrm{~m} \text {. }\end{array}$ & $\begin{array}{l}\text { Microenterprises were the leading } \\
\text { businesses in the two LGAs. }\end{array}$ \\
\hline $\begin{array}{l}7.2 . \quad \text { Capital base } \\
\text { changed in the last } 3 \\
\text { years? }\end{array}$ & $\begin{array}{l}52.8 \% \text { increased, } 34.7 \% \text { was } \\
\text { static, and } 12.5 \% \text { decreased. }\end{array}$ & $\begin{array}{l}51.4 \% \text { increased, } 37.3 \% \text { was } \\
\text { static, and } 11.3 \% \text { decreased. }\end{array}$ & $\begin{array}{l}\text { A significant number of enterprise } \\
\text { owners indicated that their capital base } \\
\text { either improved or remained static in } \\
\text { both LGAs. }\end{array}$ \\
\hline $\begin{array}{lr}7.3 . & \text { Overall } \\
\text { profitability rating of } \\
\text { enterprises }\end{array}$ & $\begin{array}{l}7.3 \% \text { was poor, } 31.0 \% \text { was } \\
\text { struggling, } 40.1 \% \text { was } \\
\text { managing, } 16.5 \% \text { was good, } \\
\text { and } 5.1 \% \text { very good. }\end{array}$ & $\begin{array}{lcr}4.6 \% \text { was } & \text { poor, } 37.3 \% \text { was } \\
\text { struggling, } & 42.2 \% & \text { was } \\
\text { managing, } & 13.5 \% \text { was } \text { good } \\
\text { and } 2.4 \% \text { very good. } & \\
\end{array}$ & $\begin{array}{l}\text { Majority of enterprise owners in both } \\
\text { LGAs indicated that they barely were } \\
\text { able to break even. }\end{array}$ \\
\hline $\begin{array}{l}\text { 7.4. Asset base } \\
\text { changed in the last } \\
\text { three years? }\end{array}$ & $\begin{array}{l}\text { Reduced } 15.4 \% \text {, was static } \\
24.9 \%, \quad \text { grew marginally } \\
51.3 \%, \quad \text { and grew } \\
\text { substantially } 8.4 \% \text {. }\end{array}$ & $\begin{array}{l}\text { Reduced } 9.8 \%, \quad \text { was static } \\
29.3 \%, \quad \text { grew } \quad \text { marginally } \\
55.2 \% \text {, and grew substantially } \\
5.7 \% \text {. }\end{array}$ & $\begin{array}{l}\text { More enterprises indicated that asset } \\
\text { base either improved marginally or was } \\
\text { static in both LGAs. }\end{array}$ \\
\hline $\begin{array}{l}7.5 \text {. Owners' } \\
\text { perception of factors } \\
\text { that affect enterprise } \\
\text { growth }\end{array}$ & $\begin{array}{l}\text { Enterprise knowledge } \\
21.6 \% \text {, insecurity } 30.1 \% \text {, } \\
\text { purchasing power } 30.4 \% \text {, } \\
\text { evil forces } 1.6 \% \text {, number of } \\
\text { dependants } 16.3 \%\end{array}$ & $\begin{array}{l}\text { Enterprise knowledge } 25.4 \% \text {, } \\
\text { insecurity } 21.8 \% \text {, purchasing } \\
\text { power } 31.2 \% \text {, evil forces } 1.2 \% \text {, } \\
\text { number of dependants } 20.4 \%\end{array}$ & $\begin{array}{l}\text { Purchasing power, knowledge, } \\
\text { dependants, and insecurity were leading } \\
\text { factors inhibiting growth of businesses } \\
\text { in both LGAs. }\end{array}$ \\
\hline
\end{tabular}

\subsection{Enterprise Perception of the Tax System}

Findings on enterprise perception of the tax systemare contained in Table 15 and further summarized below:

a. Rating of the tax system: Majority of enterprise owners in both LGAs indicated that the tax system is unfair to business development.

b. Impact of tax on profitability: Evidence of adverse impact of tax on enterprises were lacking in both LGAs, and less than $20 \%$ of the enterprises in each LGA felt the threat to quit due to the tax system.

c. Satisfaction with the tax system: High tax rates, multiple taxes and corrupt practices were major dissatisfaction raised by majority of the enterprise owners.

d. Enterprise tax Compliance: Majority of enterprise owners in both LGAs claimed that they pay their taxes duly.

Table 15: Enterprise Perception of the Tax System

\begin{tabular}{|c|c|c|c|}
\hline Research Indicator & $\begin{array}{l}\text { Survey Findings - Calabar } \\
\text { South }\end{array}$ & $\begin{array}{l}\text { Survey Findings - Calabar } \\
\text { Municipality }\end{array}$ & Implications of Findings \\
\hline $\begin{array}{l}\text { 8.1. Rating of the tax } \\
\text { system }\end{array}$ & $\begin{array}{l}9.7 \% \text { was fair, } 76.3 \% \text { unfair, } \\
\text { and } 14.0 \% \text { were uncertain. }\end{array}$ & $\begin{array}{l}12.1 \% \text { was fair, } 68.5 \% \text { unfair, } \\
\text { and } 19.4 \% \text { uncertain. }\end{array}$ & $\begin{array}{l}\text { Majority of enterprise owners in } \\
\text { both LGAs indicated that the tax } \\
\text { system is unfair to business } \\
\text { development. }\end{array}$ \\
\hline $\begin{array}{l}\text { 8.2. Adverse impact of tax } \\
\text { on enterprise profitability. }\end{array}$ & $\begin{array}{l}41.2 \% \text { had no evidence of } \\
\text { adverse impact, and for } \\
18.7 \% \text { tax system may } \\
\text { compel them to quit. } 40.1 \% \\
\text { are indifference }\end{array}$ & $\begin{array}{l}41.1 \% \text { had no evidence of } \\
\text { adverse impact, and for } \\
16.2 \% \text { tax system may } \\
\text { compel them to quit. } 42.7 \% \\
\text { are indifference }\end{array}$ & $\begin{array}{l}\text { Evidence of adverse impact of tax } \\
\text { on enterprises were lacking in both } \\
\text { LGAs and less than } 20 \% \text { of } \\
\text { enterprises in each LGA felt the } \\
\text { threat to quit due to the tax system. }\end{array}$ \\
\hline $\begin{array}{l}\text { 8.3. Aspects of the tax } \\
\text { system that enterprises feel } \\
\text { dissatisfied with }\end{array}$ & $\begin{array}{l}\text { Tax rates } 24.1 \% \text {, multiple } \\
\text { taxes } 30.4 \% \text {, illegal levies } \\
16.0 \% \text {, corrupt officials }\end{array}$ & $\begin{array}{l}\text { Tax rates } 30.3 \%, \text { multiple } \\
\text { taxes } 34.1 \% \text {, illegal levies } \\
16.5 \%, \quad \text { corrupt officials }\end{array}$ & $\begin{array}{l}\text { High tax rates, multiple taxes and } \\
\text { corrupt practices were major } \\
\text { concerns raised by enterprise }\end{array}$ \\
\hline
\end{tabular}




\begin{tabular}{|c|c|c|c|}
\hline & $\begin{array}{l}26.3 \%, \quad \text { misuse } \\
\text { receipts } 3.2 \%\end{array}$ & $\begin{array}{l}15.4 \% \text {, and misuse of tax } \\
\text { receipts } 3.7 \%\end{array}$ & owners. \\
\hline $\begin{array}{lll}8.4 . & \text { Enterprises } & \text { paying } \\
\text { taxes } & & \\
\end{array}$ & $\begin{array}{l}91.7 \% \text { paid taxes, and } 8.3 \% \\
\text { did not pay taxes }\end{array}$ & $\begin{array}{l}87.2 \% \text { paid taxes, } 12.8 \% \text { did } \\
\text { not pay taxes }\end{array}$ & $\begin{array}{l}\text { Majority of enterprise owners in } \\
\text { both LGAs claimed that they pay } \\
\text { their taxes duly. }\end{array}$ \\
\hline
\end{tabular}

\subsection{Key Findings}

\section{Key Findings, Recommendations, And Conclusion}

Generally, the pattern of responses from enterprises in both municipal LGAs was similar, understandably because both LGAs make up the State Capital.

- Employees' Preferences of Enterprises: In both LGAs, there was no evidence of gender discrimination in employment, most enterprises had 5 employees or less, there was higher preference of full time workers, Calabar Municipality required more technically skilled workers than Calabar South perhaps because it had more medium enterprises. In both LGAs, enterprises required capacity building in specialized technical, managerial and marketing fields.

- Demographics and Educational Status of Enterprise Owners/Operators: Male owned businesses were slightly more than female owned enterprises in both LGAs, and most enterprise owners spoke English and Pidgin English. Majority of enterprise owners were in the age brackets $25-45$ years, and more enterprise owners were married (and possibly had direct and extended family dependants). Few enterprise owners indicated being physically challenged in both Calabar Municipality and Calabar South LGA. Majority of enterprise owners from both LGAs had minimum of secondary school education.

- Enterprise Type and Sector: In both LGAs, enterprises were majorly in the "services" sector, particularly "other services" (mainly in hair dressing/barbing, and tailoring/fashion designing), and wholesale and retail trade. Fewer enterprises in both LGAs had branches, and much fewer were partnerships and limited liability companies.

- Bankability of Enterprises: Fewerenterprises in both LGAs had functional bank accounts. More enterprises both LGAs sourced venture capital from own savings and family members. A large number had expansion plan. Interest charges, ignorance, and poor access to loans were leading factors.

- $\quad$ Accessibility of BDS Services by Enterprises: Fewrespondentsin both LGAs had prior apprenticeship training and mentoring. Few in both LGAs did benefited from any form of BDS. Majority in both LGAs perceived that support from the LGAs was poor. Lastly, in both LGAs, cheaper loans and secure markets were what enterprises required to improve their businesses.

- Level of business formalization: Asignificant number of enterprises in both LGAs did not register their business, and several registered businesses were sole proprietorships.

- Growth Prospects of Enterprises: In bothLGAs, severalrespondents indicated that their capital base either improved or remained static, and they were barely able to break even. Equally, the asset base of respondents in both LGAs did not grow substantially. In both LGAs, low purchasing power, inadequate knowledge, large number of dependants, and insecurity were the leading de-enablers of enterprise growth.

- $\quad$ Enterprise Perception of the Tax System: Although without evidence, majority of enterprise owners in both LGAs indicated that the tax system is unfair to business development due to high tax rates, multiple taxes and corrupt practices in the tax system. Enterprise growth-sensitive fiscal policy is needed to incentivize MSMEs in the two LGAs.

Table 16: Summary of Findings and Policy Imperatives

\begin{tabular}{|c|c|c|c|}
\hline \multirow{2}{*}{$\begin{array}{l}\text { KEY RESEARCH } \\
\text { INDICATOR }\end{array}$} & \multicolumn{2}{|c|}{ SUMMARY OF FINDINGS } & \multirow[t]{2}{*}{ POLICY IMPERATIVES } \\
\hline & Calabar South & Calabar Municipality & \\
\hline $\begin{array}{l}\text { 1. Marital Status of } \\
\text { enterprise owners }\end{array}$ & $\begin{array}{l}69 \% \text { enterprise owners were } \\
\text { married, and mostly likely had } \\
\text { direct and indirect dependants }\end{array}$ & $\begin{array}{l}68 \% \text { enterprise owners } \\
\text { were married. and mostly } \\
\text { likely had direct and } \\
\text { indirect dependants. }\end{array}$ & $\begin{array}{l}\text { There is likelihood that properly targeted } \\
\text { but poorly monitored loans and subsidies } \\
\text { for enterprise development are diverted to } \\
\text { solve problems of dependants. }\end{array}$ \\
\hline $\begin{array}{l}\text { 2. Distribution of } \\
\text { enterprises by sector. }\end{array}$ & 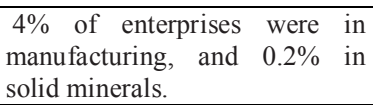 & $\begin{array}{l}4 \% \text { of enterprises were in } \\
\text { manufacturing, and } 0 \% \text { in } \\
\text { solid minerals. }\end{array}$ & $\begin{array}{l}\text { Growth of processing activities linked to } \\
\text { natural resources sectors can engender } \\
\text { value chain development. }\end{array}$ \\
\hline $\begin{array}{l}\text { 3. Bankability of } \\
\text { Enterprises }\end{array}$ & $\begin{array}{l}83 \% \text { sourced venture capital } \\
\text { from own saving and family } \\
\text { members. }\end{array}$ & $\begin{array}{llr}73 \% & \text { sourced venture } \\
\text { capital from own saving } \\
\text { and family members. }\end{array}$ & $\begin{array}{l}\text { Rendering information on lending } \\
\text { opportunities of different banks more } \\
\text { accessible will promote bankability of } \\
\text { enterprises. }\end{array}$ \\
\hline $\begin{array}{l}\text { 4. Accessibility of } \\
\text { BDS Services by } \\
\text { Enterprises }\end{array}$ & $\begin{array}{l}5 \% \text { respondent benefitted from } \\
\text { MEDA's BDS, } 2 \% \text { BDS from } \\
\text { other MDAs, and } 2 \% \text { from the } \\
\text { LGCs. }\end{array}$ & $\begin{array}{l}\text { From MEDA's } 6 \% \text {, other } \\
\text { MDAs } 3 \% \text {, and } 2 \% \text { from } \\
\text { the LGCs. }\end{array}$ & $\begin{array}{l}\text { MEDA's BDS should target different } \\
\text { groups of BDS seekers and avoid a } \\
\text { situation where rural based beneficiaries are } \\
\text { crowded out. }\end{array}$ \\
\hline
\end{tabular}




\begin{tabular}{|c|c|c|c|}
\hline $\begin{array}{l}\text { 4. Key de-enablers of } \\
\text { business } \\
\text { formalization) }\end{array}$ & $\begin{array}{l}\text { Incentives } 7 \%, \text { cost of } \\
\text { registration } \\
\text { information } 11 \% \text {, and fear of } \\
\text { taxation } 12 \% .\end{array}$ & $\begin{array}{l}\text { Incentives } 7 \%, \text { cost of } \\
\text { registration } 29 \%, \\
\text { information } 9 \% \text {, and fear of } \\
\text { taxation } 6 \% .\end{array}$ & $\begin{array}{l}\text { Improved government-enterprise } \\
\text { dialogue will assist in business } \\
\text { formalization promotion. }\end{array}$ \\
\hline $\begin{array}{l}\text { 5. Enterprise owners' } \\
\text { perception of factors } \\
\text { that affect enterprise } \\
\text { growth }\end{array}$ & $\begin{array}{l}\text { Enterprise knowledge } 22 \% \text {, } \\
\text { insecurity } 30 \% \text {, purchasing } \\
\text { power } 40 \% \text {, evil forces } 2 \% \text {, } \\
\text { number of dependants } 17 \%\end{array}$ & $\begin{array}{l}\text { Enterprise knowledge } 25 \% \text {, } \\
\text { insecurity } 22 \% \text {, purchasing } \\
\text { power } 37 \% \text {, evil forces } 1 \% \text {, } \\
\text { number of dependants } 21 \%\end{array}$ & $\begin{array}{l}\text { The mix of public-private dialogue, } \\
\text { subsidy, education, market making, and } \\
\text { equipment support will improve the outlook } \\
\text { for enterprise owners. }\end{array}$ \\
\hline $\begin{array}{ll}6 . & \text { Historical } \\
\text { advantage } & \end{array}$ & $\begin{array}{l}\text { History of seafaring and fishing } \\
\text { can support eco-aquaculture, } \\
\text { boating festivals, and organized } \\
\text { ferrying of persons and goods to } \\
\text { Oron, Mbo, and Cameroon. }\end{array}$ & $\begin{array}{l}\text { The age long culture of } \\
\text { trade and leisure can } \\
\text { support growth of more } \\
\text { corner shops, hotels, } \\
\text { recreational centres, and } \\
\text { theme parks. }\end{array}$ & $\begin{array}{l}\text { MEDA's BDS services should factor in } \\
\text { historical advantages and disposition of } \\
\text { people in the respective LGAs. }\end{array}$ \\
\hline $\begin{array}{l}7 . \quad \text { Geographical } \\
\text { advantage }\end{array}$ & $\begin{array}{l}\text { Population projected to reach } \\
245,550 \text { by } 2015 \text {. }\end{array}$ & $\begin{array}{l}\text { Population projected to } \\
\text { reach } 250,000 \text { by } 2015 \text {. }\end{array}$ & $\begin{array}{l}\text { Growing population offer enormous market } \\
\text { prospects for variety of goods and services }\end{array}$ \\
\hline $\begin{array}{l}\text { 8. Socioeconomic } \\
\text { milieu }\end{array}$ & $\begin{array}{l}\text { Perception of Calabar South as } \\
\text { being generally unsafe. It is } \\
\text { needful check excesses "area } \\
\text { boy". }\end{array}$ & $\begin{array}{l}\text { Hosts several underutilized } \\
\text { development infrastructures } \\
\text { - seaport, airport, FTZ, and } \\
\text { Tinapa Resort. }\end{array}$ & $\begin{array}{l}\text { More public education and peace building } \\
\text { efforts required for both Calabar South and } \\
\text { the Municipality. Strategic planning } \\
\text { towards ensuring optimal use of facilities in } \\
\text { the Municipality critical for speedy } \\
\text { modernization of Calabar city, and CRS. }\end{array}$ \\
\hline
\end{tabular}

\subsection{Recommendations}

Arising from the above findings, the following recommendations were considered valuable for the growth of microenterprise development strategy (MDS) in Cross River State:

1. BDS should have components for financial facilitation, value chain development, and market making. Concessionary credit facilities, equipment and subsidies for budding entrepreneurs should be properly tracked and monitored to check possible misuse or diversion for other uses.

2. Entrepreneurial culturing should be mainstreamed in all on-going and future empowerment programmes of State MDAs, donors, the LGCs, and NGOs working in the State. To achieve this, human empowerment generally, and poverty reduction programmes in particular, should be linked to entrepreneurial culturing, and IEC material for promoting entrepreneurial culturing can be produced in local languages and Pidgin English.

3. Given the poverty level and high technical skills' deficiency of most enterprise owners. More youths should be encouraged to learn technical skill intensive vocations, and having acquired the skills those interested in starting new businesses should be supported to do so. More education is required to update enterprise owners with information on how registration with $\mathrm{CAC}$ has become much easier. Science and technology education promotion, and encouraging out-of-school youths to learn vocational skills will promote employability and raise interest in starting new businesses.

4. Continuing interface of MEDA with IMOs and banks is required to promote enterprise bankability, and MEDA needs to incorporate apprenticeship training and mentoring in its BDS programmes.

5. The State Government needs to address issues of taxation, cost of lending, market making, affordability of machineries and other production inputs, and eased access to land.

\section{Table 17: Findings and Recommendations}

\begin{tabular}{|l|l|}
\hline Key Findings & Recommendations \\
\hline $\begin{array}{l}\text { 1. Poverty level of enterprise owners: 68.0 percent } \\
\text { had families and possibly large number of direct and } \\
\text { indirect dependants; given the preference for early } \\
\text { marriages, celebration of child bearing, and } \\
\text { commitments to the extended family system. }\end{array}$ & $\begin{array}{l}\text { Financial empowerment should be incorporated into MEDA's } \\
\text { empowerment programmes of State MDAs, donors, and } \\
\text { NGOs/CSOs. Collaborative platforms that connects MEDA's } \\
\text { MDS to the empowerment budget of other MDAs, donors, and } \\
\text { CSOs/NGOs in the State should be created. }\end{array}$ \\
\hline $\begin{array}{l}\text { 2. Value addition through processing: 3.6 percent of } \\
\text { respondents were in processing. Few Crossriverians } \\
\text { engaged in technical skill intensive vocations that are } \\
\text { linked to natural resources sectors. }\end{array}$ & $\begin{array}{l}\text { Development of processing/manufacturing that is linked to } \\
\text { natural resources sectors can promote value chain development. } \\
\text { vocations will promote activities in processing/manufacturing. }\end{array}$ \\
\hline $\begin{array}{l}\text { 3. Bankability of Enterprises: } 88.2 \text { percent had not } \\
\text { obtained loans before, and only } 1.5 \text { percent had done } \\
\text { business with specialized banks that offer } \\
\text { concessionary conditions. Very few demonstrated } \\
\text { capacity for preparing bankable proposals. }\end{array}$ & $\begin{array}{l}\text { Sustaining ongoing interface of MEDA with banks and } \\
\text { enterprise groups will improve bankability of enterprises. There } \\
\text { isterprises on lending opportunities offered by specialized } \\
\text { banks. MEDA needs to develop robust institutional framework } \\
\text { and market for project financing. }\end{array}$ \\
\hline $\begin{array}{l}\text { 3. Entrepreneurial Culturing: } 52.4 \text { percent had no } \\
\text { prior apprenticeship training and mentoring. 95.2 }\end{array}$ & $\begin{array}{l}\text { Promoting apprenticeship training and mentoring should be a } \\
\text { critical component of the MDS. Majority of enterprises indicated }\end{array}$ \\
\hline
\end{tabular}




\begin{tabular}{|l|l|}
\hline $\begin{array}{l}\text { percent did not benefit from any BDS. Only 0.3 percent } \\
\text { benefited from MEDA's activities. } 47.2 \text { percent did not } \\
\text { receive support from LGCs. }\end{array}$ & $\begin{array}{l}\text { not receiving meaningful support from MEDA and the LGCs. } \\
\text { MEDA's MDS should rural centred programmes distinguished } \\
\text { from the urban programmes to avoid the crowding out of rural } \\
\text { based beneficiaries. }\end{array}$ \\
\hline $\begin{array}{l}\text { 4. Business Formalization: 52.0 percent of enterprises } \\
\text { did not know how to formalize, } 28.6 \text { percent attributed } \\
\text { it to financial constraints, } 9.9 \text { percent to inadequate } \\
\text { information, and } 8.9 \text { percent fear of taxation. }\end{array}$ & $\begin{array}{l}\text { Rendering the business environment more hospitable, } \\
\text { particularly eliminating excessive taxation and rent seeking, will } \\
\text { promote formalization of enterprises. MEDA should intensify its } \\
\text { enlightenment and educational programmes to promote business } \\
\text { formalization. }\end{array}$ \\
\hline $\begin{array}{l}\text { 5. Asset Base in the Last } 3 \text { Years: } 48.2 \text { percent } \\
\text { indicated that asset base grew marginally, 30.4 percent } \\
\text { believed it remained static, 13.7 percent believed it } \\
\text { reduced, and } 7.7 \text { percent believed it grew substantially. }\end{array}$ & $\begin{array}{l}\text { Substantial element of subsidy and equipment support, in the } \\
\text { form of opportunities for leasing, hire purchase, waivers for } \\
\text { imported machine components, should be incorporated into the } \\
\text { MDS to augment the asset base of enterprises. }\end{array}$ \\
\hline
\end{tabular}

\subsection{Conclusion}

The study set out to gather information on enterprises using the survey method. This survey focused on Calabar South and Calabar Municipality and a total of 3660 enterprise owners/operators were interviewed. Extending the study to other LGAs in the State is strongly recommended. It is hoped that the study outcomes will assist the development of a holistic MDS for the State Government, and assist other State MDAs and donors to engage entrepreneurship development programmes with vital information. The study concludes as follows:

a) Substantial element of financial empowerment should be incorporated into the MSMEs intervention programmes in the State.

b) Promoting development of processing/manufacturing is important for value chain development.

c) Encouraging more youths to learn technical skills and intensive vocations will support new business startups and improve youth employability.

d) Improved interface of MSMEs with banking institutions and IMOs will improve bankability of enterprises.

e) Promoting apprenticeship training and mentoring, and business formalization should be critical components of MDS.

f) Rendering the business environment more competitive and hospitable with tax incentives, affordable credit, secure markets, accessible machineries and other technical inputs, and a deregulated land tenure system will promote development of enterprises in the State.

\section{References}

[1]. Edgcomb, Elaine L. and Tamra Thetford (2013), Job Creation: Entrepreneurship Approaches. Microenterprise Development as Job Creation. The Aspen Institute, FIELD (Microenterprise Fund for Innovation, Effectiveness, Learning and Dissemination).

[2]. GEMS-3 (2012), The Business Environment and Investment Climate - Investment Study, Cross River State, February (a DFID Funded Project.

[3]. GEMS 3 Baseline and Diagnostic Survey for Tax Harmonization and Related Matters in three Pilot LGAs of Cross River State Calabar South, Calabar Municipality, and Ikom LGAs, February (2013),(a DFID Funded Project).

[4]. Gulani, Musa Garba and Aisha Usman (2013), Financing Small and Medium Scale Enterprises (SMEs): A Challenge for Entrepreneurial Development in Gombe State, Asian Journal of Business and Management Sciences 2(9) 17-23.

[5]. Kanayo, Ogujiuba, Fadila Jumare and Stiegler Nancy (2013), Challenges of Microfinance Access in Nigeria: Implications for Entrepreneurship Development Mediterranean Journal of Social Sciences 4 (6) $611-618$.

[6]. Olu, Ojo (2009), Impact of Microfinance on Entrepreneurial Development: The Case of Nigeria. The International Conference on Economics and Administration, Faculty of Administration and Business, University of Bucharest, Romania ICEA - FAA Bucharest, 14-15th November.

[7]. Seibel, Hans Dieter (2007), The Role of Microfinance in Rural Microenterprise Development: Syngenta - Foundation for sustainable agriculture February.

[8]. USAID (2008), Impact Assessment of the Growth-Oriented Microenterprise Development Program Baseline Research Report Microreport No. 104, April.

[9]. World Bank (2010), Doing Business in Nigeria 2010: Comparing Regulation in 36 States,Abuja FCT and 183 Economies. 